\title{
Nitrogen cycle and ecosystem services in the Brazilian La Plata Basin: anthropogenic influence and climate change
}

\author{
Watanabe, M. ${ }^{a *}$, Ortega, E. ${ }^{a}$, Bergier, $I^{b}$ and Silva, JSV. ${ }^{c}$ \\ ${ }^{a}$ Departamento de Engenharia de Alimentos, Faculdade de Engenharia de Alimentos, \\ Universidade Estadual de Campinas - UNICAMP, Monteiro Lobato St., 80, Barão Geraldo, \\ CP 6121, CEP 13083-862, Campinas, SP, Brazil

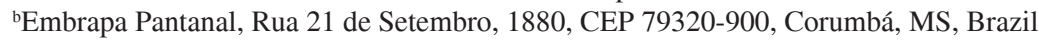 \\ 'Embrapa Informática Agropecuária, Av. André Tosello, 209, Barão Geraldo, \\ CP 6041, CEP 13083-886, Campinas, SP, Brazil \\ *e-mail: marcosw@fea.unicamp.br
}

Received February 13, 2012 - Accepted February 22, 2012 - Distributed August 31, 2012

(With 9 figures)

\begin{abstract}
The increasing human demand for food, raw material and energy has radically modified both the landscape and biogeochemical cycles in many river basins in the world. The interference of human activities on the Biosphere is so significant that it has doubled the amount of reactive nitrogen due to industrial fertiliser production (Haber-Bosch), fossil fuel burning and land-use change over the last century. In this context, the Brazilian La Plata Basin contributes to the alteration of the nitrogen cycle in South America because of its huge agricultural and grazing area that meets the demands of its large urban centres - Sao Paulo, for instance - and also external markets abroad. In this paper, we estimate the current inputs and outputs of anthropogenic nitrogen (in $\mathrm{kg} \mathrm{N}_{\mathrm{km}}{ }^{-2} \cdot \mathrm{yr}^{-1}$ ) in the basin. In the results, we observe that soybean plays a very important role in the Brazilian La Plata, since it contributes with an annual entrance of about $1.8 \mathrm{TgN}$ due to biological nitrogen fixation. Moreover, our estimate indicates that the export of soybean products accounts for roughly $1.0 \mathrm{TgN}$ which is greater than the annual nitrogen riverine exports from Brazilian Parana, Paraguay and Uruguay rivers together. Complimentarily, we built future scenarios representing changes in the nitrogen cycle profile considering two scenarios of climate change for 2070-2100 (based on IPCC's A2 and B2) that will affect land-use, nitrogen inputs, and loss of such nutrients in the basin. Finally, we discuss how both scenarios will affect human well-being since there is a connection between nitrogen cycle and ecosystem services that affect local and global populations, such as food and fibre production and climate regulation.
\end{abstract}

Keywords: nitrogen, nitrogen cycle, climate change, ecosystem services, La Plata Basin.

\section{Ciclo de nitrogênio e serviços ecossistêmicos na Bacia do Prata brasileira: influência antropogênica e mudanças climáticas}

\begin{abstract}
Resumo
A crescente demanda humana por alimentos, matérias-primas e energia modificou radicalmente a paisagem e os ciclos biogeoquímicos de inúmeras bacias hidrográficas no mundo. A interferência das atividades humanas na Biosfera é tão grande que já duplicou a quantidade de nitrogênio reativo com a produção industrial de fertilizantes, a queima de combustíveis fósseis e a mudança de uso da terra no século XX. A Bacia do Prata brasileira contribui para a alteração do ciclo do nitrogênio na América do Sul, por causa da sua extensa área e da marcante ocupação agrícola e pecuária, que atende à demanda de seus grandes centros urbanos - São Paulo, por exemplo - e de mercados fora do Brasil. Neste estudo, foram estimados os valores das principais entradas e saídas de $\mathrm{N}$ atuais em razão da ação antrópica na bacia. O complexo da soja desempenha um papel importante, pois contribui com uma entrada anual de quase $1.8 \mathrm{TgN}$ por causa da fixação biológica na bacia. Além disso, a exportação de produtos oriundos da soja é estimada em 1.0 TgN, um valor maior que a exportação de nitrogênio total dos rios Paraná, Paraguai e Uruguai (na porção de área brasileira) juntos. Também foram tomadas como hipóteses situações futuras para o comportamento do ciclo de $\mathrm{N}$ na bacia, considerando-se dois cenários de mudanças climáticas para o período 2070-2100 (baseados em A2 e B2, do IPCC), que poderão influenciar o uso da terra, as entradas e as perdas de $\mathrm{N}$ na bacia. Por fim, é discutido como tais cenários irão alterar o bem-estar da população, pois há uma conexão entre o ciclo do nitrogênio e os serviços ecossistêmicos, tais como a produção de alimentos e a regulação climática.
\end{abstract}

Palavras-chave: nitrogênio, ciclo do nitrogênio, mudanças climáticas, serviços ecossistêmicos, Bacia do Prata. 


\section{Introduction}

There is little doubt that the fluxes and reservoir masses of the elements carbon, nitrogen and phosphorus have been modified by human activities (Mackenzie et al., 2002). Anthropogenic inputs of nitrogen at the global scale have doubled the amount of reactive nitrogen $(\mathrm{Nr})$ in terrestrial environment over the past century, mainly because of two human activities: food and energy production (Galloway et al., 2004). According to Rockström et al. (2009), among the nine planetary boundaries, humanity has already transgressed three: climate change, biodiversity loss and the nitrogen global cycle. Although there is significant uncertainty regarding the duration over which boundaries can be transgressed before causing unacceptable environmental change, the harmful effects of environmental degradation has already caused the loss of $60 \%-15$ of $24-$ of the ecosystem services examined during the Millennium Ecosystem Assessment (MEA, 2005).

Since the capacity of ecosystems to provide services derives directly from the operation of natural biogeochemical cycles, the alteration of the nitrogen cycle is affecting the provision of many ecosystem services which, in turn, affect human welfare. For instance, excessive flows of nitrogen contribute to acidification of freshwater and terrestrial ecosystems, eutrophication of freshwater and coastal marine ecosystems - with consequences to biodiversity. Moreover, Nr emissions deplete the air quality due to the creation of ozone in the troposphere (which causes loss of agricultural productivity and respiratory diseases), destroys the ozone layer when it gets to the stratosphere (which contributes to the increased incidence of skin cancer) and disturbs the climate due to the high global warming potential of nitrous oxide (MEA, 2005).

Considering the importance of the nitrogen cycle to human wellbeing and the fact that the most rapid changes in ecosystems are taking place in developing countries (MEA, 2005), this paper will assess the anthropogenic nitrogen cycle in the Brazilian La Plata Basin (BLPB) - which is one of the most important watersheds in Brazil because of its large agricultural area and growing population in urban centres, such as the city of São Paulo. Moreover, this paper will include the IPCC's emission scenarios (A2 and B2) in order to discuss - in qualitative terms - how climate change will affect the future nitrogen cycle in the period of 2070-2100, since changes in precipitation and temperature increases can lead to changes in ecosystem processes related to the nitrogen cycle.

\section{Material and Methods}

\subsection{Area of study: Brazilian La Plata Basin}

The La Plata Basin is the fifth largest watershed in the world and the second in South America. Its area encompasses 3.1 million $\mathrm{km}^{2}$ in five countries: Argentina, Bolivia, Brazil, Paraguay and Uruguay. The main river is the Paraná which is named La Plata when Paraná River joins Uruguay River near Buenos Aires before getting to the Atlantic Ocean. La Plata basin has an enormous influence in Latin America's welfare given that $70 \%$ of the GDP and $50 \%$ of the population of five countries is within the basin (ANA, 2001).

The largest area of La Plata Basin belongs to Brazil about $46 \%$ of the total. The overall area of the Brazilian La Plata Basin (BLPB) comprises about 1.41 million $\mathrm{km}^{2}$ and represents the more intensively occupied area by humans in the South American continent. In Brazil, BLPB is distributed over nine states: Mato Grosso, Mato Grosso do Sul, Goiás, Distrito Federal, Minas Gerais, São Paulo, Paraná, Santa Catarina and Rio Grande do Sul. Moreover, a variety of ecosystems are found within the boundaries of BLPB: Wetlands (Pantanal), Atlantic Forest (Mata Atlantica), Savanna (Cerrado) and Grasslands (the Pampas).

Integrating data from the map of Embrapa Informática Agropecuária (see Figure 1), land-use in BLPB is basically characterised by areas of agriculture and livestock breeding: pasture land cover is about $550,610 \mathrm{~km}^{2}$ representing $39 \%$ of the total area, and agriculture is roughly $273,369 \mathrm{~km}^{2}$ representing about $19 \%$ of the total basin. The remaining area is occupied by native forest $\left(33 \%\right.$ or $\left.469,724 \mathrm{~km}^{2}\right)$, reforestation $\left(2 \%\right.$ or $\left.30,147 \mathrm{~km}^{2}\right)$, urban areas $(1 \%$ or $12,508 \mathrm{~km}^{2}$ ) and other land-uses (6\%).

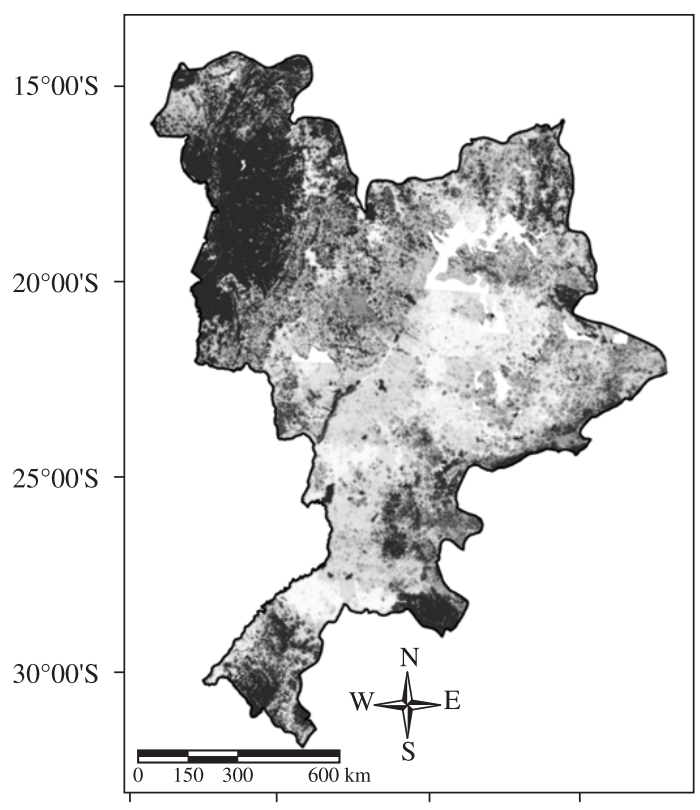

\begin{tabular}{|ll|}
$60^{\circ} 00^{\prime} \mathrm{W} \quad 55^{\circ} 00^{\prime} \mathrm{W}$ & $50^{\circ} 00^{\prime} \mathrm{W} \quad 45^{\circ} 00^{\prime} \mathrm{W}$ \\
\hline$\square$ Agriculture & $\square$ Water \\
$\square$ Anthropic areas & $\square$ Undefined \\
$\square$ Urban influence & $\square$ Pasture \\
$\square$ Unclassified & $\square$ Reforestation \\
$\square$ Secondary vegetation & $\square$ Primary vegetation \\
$\square$ Mined areas & \\
\hline
\end{tabular}

Figure 1. Land cover and land-use of Brazilian La Plata Basin in 2002. Map source: Embrapa-CNPTIA (Embrapa, 2010a). 
Most land-use changes, especially in the second half of the last century, were made to sustain a prominent urban development, where most of the people are concentrated. Agriculture in the southern BLPB is based on land originally part of the Atlantic Forest (Mata Atlântica), and Grasslands ecosystems. About $90 \%$ of the Atlantic Forest ecosystem has been converted to agricultural land uses since the early 1900's. Since agricultural production in southern Brazil is highly mechanised and uses a high quantity of nonrenewable inputs, such processes have resulted in high crop productivity, but have caused serious environmental damage such as soil compaction and erosion, water contamination, and vegetation devastation. The northern region of the Plata Basin includes part of the Cerrado ecosystem, which is characterised by low fertility soils that are also being gradually converted to annual crops like soybeans, wheat and maize (VAMOS, 2001).

\subsection{Measuring anthropogenic influence on nitrogen cycle in $B L P B$}

Human interference on the nitrogen cycle in BLPB is related to a growing economy and its population - approximately 60 million inhabitants - that demands food, raw material and energy. Although cities modify the environment through waste production and fossil fuel burning, the major impact to the nitrogen cycle takes place in agricultural and non-degraded pasture areas which sustain city's demand for goods and services through biological nitrogen fixation and use of manure and chemical fertilisers (Haber Bosch process).

Based on Filoso et al. (2003) and Filoso et al. (2006), this paper aims to evaluate the level of human interference on BLPB's nitrogen cycle due to biological nitrogen fixation (BNF) in cropland and pastures, use of fertiliser in agriculture and anthropogenic depositions ( $\mathrm{NO}_{\mathrm{y}}$ and $\mathrm{NH}_{\mathrm{x}}$ ) derived from consumption of fossil fuel, biomass burning and losses of nitrogenous fertiliser. Moreover, BLPB's nitrogen outputs are also affected by human activities such as the trade of farm commodities (with high protein content such as soybean and meat) to external markets and the riverine export of nitrogen in which water carries a fraction of the anthropogenic input of nitrogen to freshwater systems and to the Atlantic Ocean. All these inputs and outputs will be assessed with the purpose of investigating some aspects of the nitrogen cycle in this river basin (for the year 2002). Figure 2 is based on the System's Ecology approach and illustrates the main nitrogen flows described as under the influence of human activities in BLPB.

Therefore, to calculate the nitrogen input from fertiliser to croplands into the BLPB, it is necessary to estimate the values of several cropland areas in the basin. Usually, databases provide values of hectares cultivated for a given crop considering political borders instead of geographical features. According to relative cultivated areas of croplands

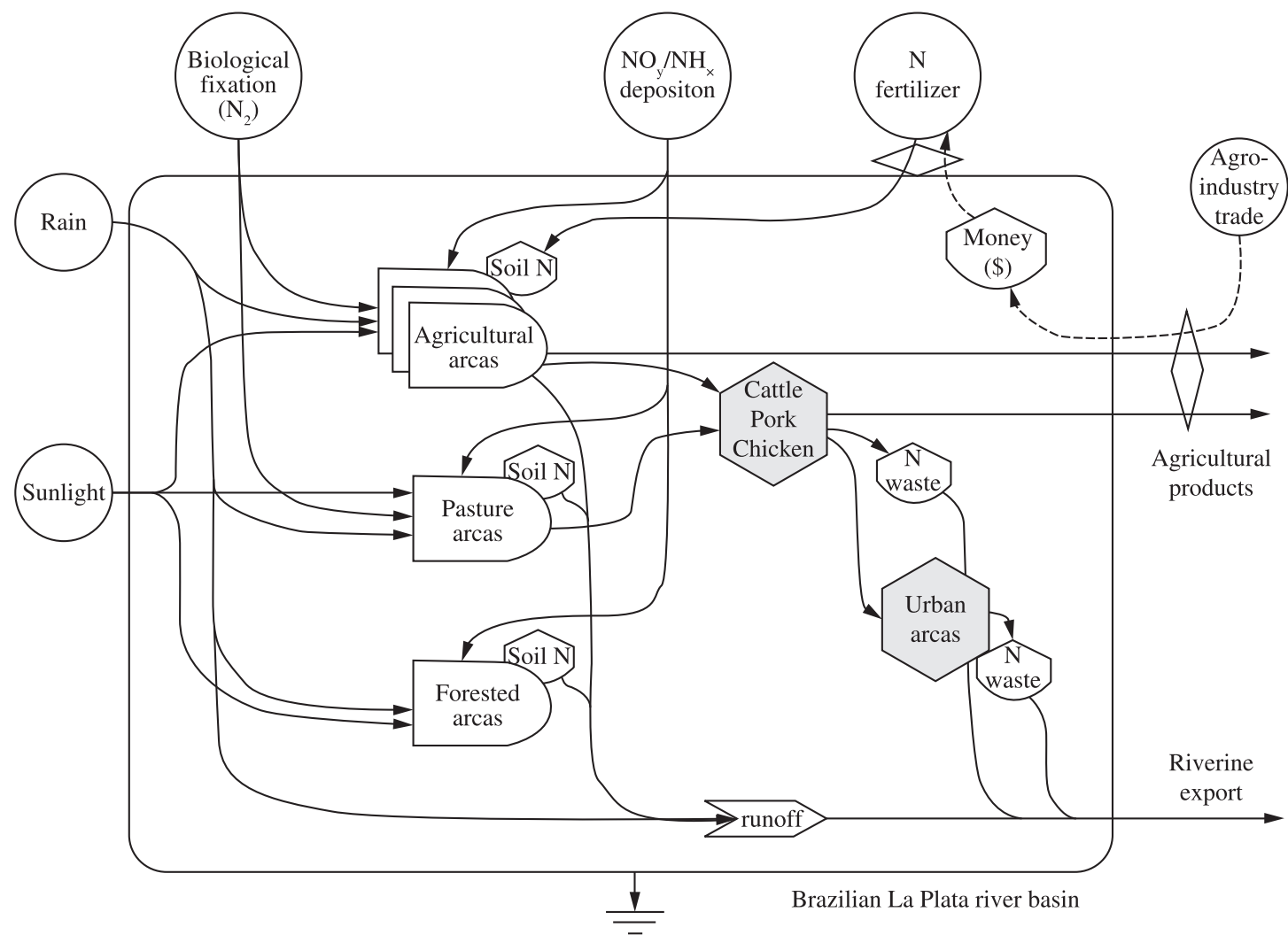

Figure 2. Representation of the main anthropogenic nitrogen inputs (placed at the top) and outputs (on the right) in Brazilian La Plata Basin. 
by state (FNP, 2006) and making a superposition of cropland maps with the BLPB map (Figure 1), it was possible to estimate the productive area for the crops in the basin. Cropland maps were obtained online from Companhia Nacional de Abastecimento (CONAB, 2011) and Hervé and Melo (2008).

We assumed that BLPB is an exporter river basin with the purpose of calculating BLPB's nitrogen outputs. Data were collected with the aim to estimate soybean, soy meal, beef, pork and poultry exports since they represent the major categories of farm products with high nitrogen content and significant exported amount. Since there is neither data regarding exports and imports of food among Brazilian states nor among river basins, we considered BLPB exported food and feed according to the pace of Brazilian exports (in the case of soybean, soy meal and beef) in 2002. Nevertheless, this procedure represents a first approximation to estimate the percentage of the total food and feed produced by states and traded to external markets. Data related to production and exports of soybean and soy meal were obtained in FNP (2006). In the case of beef, data were based on data collected by Igreja et al. (2006) from the Instituto Brasileiro de Geografia e Estatística (IBGE) and Anuário da Pecuária Brasileira - ANUALPEC (FNP, 2006); meanwhile, information on pork meat was obtained from the ABIPECS association (2002), and poultry data were obtained from the ABEF association (2002). Pig and chicken livestock distribution was determined according to maps found in IBGE (2006). The conversion of food to mass of nitrogen, protein content of food products was obtained in the Brazilian table of food composition (UNICAMP, 2006) elaborated by the Núcleo de Estudos e Pesquisas em Alimentação (NEPA, 2011) in the College of Food Engineering at State University of Campinas. We then assumed a proportion of $16 \mathrm{~g}$ of nitrogen per $100 \mathrm{~g}$ of food protein.

\section{Results}

\subsection{Anthropogenic nitrogen inputs to $B L P B$}

\subsubsection{BNF in agriculture}

In this paper, nitrogen inputs from biological nitrogen fixation (BNF) in croplands were considered an anthropogenic input because human land-use changes are able to modify BNF rates through conversion of ecosystems into agroecosystems. While native vegetation is able to balance nitrogen inputs and outputs, some leguminous crops require larger quantities of nitrogen to sustain plant growth and therefore fix higher amounts of nitrogen from the atmosphere compared to natural vegetation. In Brazil, soybean production is the most important crop relying on $\mathrm{BNF}$ and it is known that inputs of nitrogen from fertilisers tend to zero (Filoso et al., 2006). According to Filoso et al. (2006) we can assume an average BNF rate of $170 \mathrm{kgN} \cdot \mathrm{ha}^{-1} \cdot \mathrm{yr}^{-1}$ for soybean cultivation in Brazil. Therefore, considering our estimate of cultivated area with soybean in BLPB (about 10.8 million ha in 2002),
BNF would introduce about 1.83 teragrammes of nitrogen $(\operatorname{Tg} \mathrm{N})$ per year.

Rice and beans cultivation also contribute to BNF inputs to the basin; however it is related to small amounts of nitrogen. Based on Baldani et al. (2002) and Crusciol et al. (2003), we assumed an average of $20 \mathrm{~kg} \mathrm{~N} \cdot \mathrm{ha}^{-1} \cdot \mathrm{yr}^{-1}$ is expected in fields with rice cultivation. Based on the estimate of 720 thousand ha in 2002, rice would contribute to $0.01 \mathrm{TgN}$ to the basin. Cultivation of beans is able to fix about 3 kg N.ha-1.yr ${ }^{-1}$ (Santos, 2009 apud Souza, 2010); considering a total area of 1.2 million ha, FBN would therefore reach roughly $0.03 \mathrm{Tg} \mathrm{N}$.

The remaining crops cultivated in BLPB (sugarcane, corn, wheat, cotton, oranges, coffee and silviculture) are not related to significant BNF rates (unless cultivated using root inoculation techniques) and most of their nitrogen demand comes from external nitrogen input obtained during application of chemical fertiliser.

\subsubsection{BNF in pastures}

According to Embrapa Informática Agropecuária, the main land-use in BLPB is pasture: about 40\% (55 million ha, in 2002) were dedicated to cattle livestock breeding. Pasture land-use change are distributed surrounding the Pantanal region (the main Brazilian wetland in Mato Grosso and Mato Grosso do Sul states), alongside Parana, Paraguay and Uruguay rivers in the west of São Paulo, south of Minas Gerais, south of Goias, northwestern and southeastern Paraná and western regions of Santa Catarina and Rio Grande do Sul states (see legend and map in Figure 1).

Considering a conservative fixation $\mathrm{BNF}$ rate for Brazilian pastures (15 kg N.ha ${ }^{-1} \cdot \mathrm{yr}^{-1}$, Filoso et al., 2006) and considering the assumption that $50 \%$ of pasture areas in Brazil are not able to fix nitrogen due to degradation and overgrazing (Filoso et al., 2006), we estimate that pastures can potentially provide an average of $0.41 \mathrm{Tg} \mathrm{N}$.

\subsubsection{Nitrogen chemical fertiliser application in cropland}

Nitrogen chemical fertiliser is required by crops with low BNF performance, therefore artificial inputs of reactive nitrogen are introduced in BLPB in order to maintain high productivity of croplands. Nitrogen loads within fertiliser such as ammonium nitrate, ammonium sulfate, NPK mixes (diverse proportions in terms of nitrogen, phosphorus and potash) strongly vary depending on plantation type, weather, soil type, management and expected productivity.

We assumed average values based on fertiliser recommendations or actual use of fertiliser in Brazilian cropland areas found in the literature: $80 \mathrm{~kg} \mathrm{~N} \cdot \mathrm{ha}^{-1} \cdot \mathrm{yr}^{-1}$ for sugarcane (Filoso et al., 2003), $96 \mathrm{~kg} \mathrm{~N} \cdot \mathrm{ha}^{-1} \cdot \mathrm{yr}^{-1}$ for corn (FNP, 2006), $90 \mathrm{~kg} \mathrm{~N} \mathrm{ha}^{-1} \cdot \mathrm{yr}^{-1}$ for rice (Fageria et al., 2003), $60 \mathrm{~kg} \mathrm{~N} \cdot \mathrm{ha}^{-1} \cdot \mathrm{yr}^{-1}$ for wheat (averages from FNP, 2006 and Wendling et al., 2007), $113 \mathrm{~kg} \mathrm{~N} \cdot \mathrm{ha}^{-1} \cdot \mathrm{yr}^{-1}$ for cotton (FNP, 2006), $166 \mathrm{~kg} \mathrm{~N} \cdot \mathrm{ha}^{-1} \cdot \mathrm{yr}^{-1}$ in oranges (FNP, 2006), $135 \mathrm{~kg} \mathrm{~N} . \mathrm{ha}^{-1} \cdot \mathrm{yr}^{-1}$ for beans (Barbosa Filho et al., 2005), $300 \mathrm{~kg} \mathrm{~N} \cdot \mathrm{ha}^{-1} \cdot \mathrm{yr}^{-1}$ for coffee (average values from 
Costa, 2006 and FNP, 2006), and $9 \mathrm{~kg} \mathrm{~N} \cdot \mathrm{ha}^{-1} \cdot \mathrm{yr}^{-1}$ for silviculture (Filoso et al., 2003).

Average nitrogen inputs from fertiliser were calculated considering the nine main crops occupying each state (or part of the state) in BLPB. Results indicate that total agricultural and silviculture inputs to the basin is about 1.79 Tg N.yr ${ }^{-1}$, highlighting corn (0.69 Tg N.yr $\left.{ }^{-1}\right)$, coffee $\left(0.33 \mathrm{Tg} \mathrm{N} . \mathrm{yr}^{-1}\right)$ and sugarcane $\left(0.28 \mathrm{Tg} \mathrm{N} \mathrm{yr}^{-1}\right)$ as the three highest loads of nitrogenous fertiliser to the basin.

\subsubsection{Anthropogenic deposition $\left(\mathrm{NO}_{y}\right.$ and $\left.\mathrm{NH}_{\mathrm{x}}\right)$}

The calculations considered deposition rates of oxidised $\left(\mathrm{NO}_{\mathrm{y}}\right)$ and reduced $\left(\mathrm{NH}_{\mathrm{x}}\right)$ nitrogen compounds in Brazil generated by the TM3 global chemistry-transport model of the University of Utrecht (Filoso et al., 2006) valid for the mid 1990's. According to these maps, the Paraná river basin received an average of $500 \mathrm{mg} \cdot \mathrm{m}^{-2} \cdot \mathrm{yr}^{-1}$ of $\mathrm{NH}_{\mathrm{x}}$ and $80 \%$ of that would be from anthropogenic sources such as fossil fuel combustion, biomass burning and fertiliser loss to atmosphere; $\mathrm{NO}_{\mathrm{y}}$ depositions would account about $175 \mathrm{mg} \cdot \mathrm{m}^{-2} \cdot \mathrm{yr}^{-1}$ of nitrogen and $70 \%$ of this deposition would be due to human activities. The same considerations have been made for Paraguay $\left(\mathrm{NH}_{\mathrm{x}}: 175 \mathrm{mg} \cdot \mathrm{m}^{-2} \cdot \mathrm{yr}^{-1}, 35 \%\right.$ anthropogenic; $\mathrm{NO}_{\mathrm{y}}: 175 \mathrm{mg} \cdot \mathrm{m}^{-2} \cdot \mathrm{yr}^{-1}, 70 \%$ anthropogenic) and Uruguay river basins $\left(\mathrm{NH}_{\mathrm{x}}: 875 \mathrm{mg} \cdot \mathrm{m}^{-2} \cdot \mathrm{yr}^{-1}, 80 \%\right.$ anthropogenic; $\mathrm{NO}_{\mathrm{y}}: 375 \mathrm{mg} \cdot \mathrm{m}^{-2} \cdot \mathrm{yr}^{-1}, 70 \%$ anthropogenic).

Based on each river basin area - Paraná $\left(880,000 \mathrm{~km}^{2}\right)$, Paraguay $\left(360,000 \mathrm{~km}^{2}\right)$ and Uruguay $\left(170,000 \mathrm{~km}^{2}\right)-$ it was possible to estimate total anthropogenic deposition to BLPB. Summing up oxidised and reduced nitrogen compounds depositions in all three river basins, a total nitrogen input of $0.69 \mathrm{Tg} \cdot \mathrm{yr}^{-1}$ was obtained.

\subsubsection{Imported food and raw material}

In terms of products, we assumed that the entrance of imported food and raw material with high nitrogen contents in significant amounts to BLPB is null. Instead, BLPB could be understood as an exporter river basin which provides soybean, soy meal, meat, pork, poultry and other products to external markets outside the basin's borders in Brazil and abroad. Therefore, most nitrogen consumed (and consequent sewage) from BLPB population is provided internally by agricultural fields or pasture lands and the flow of imported nitrogen as food and raw material tends to zero.

Figure 3 points out main nitrogen inputs provided by human interference at BLP, based on data of land-use in 2002. Average values presented below highlight the importance of biological nitrogen fixation (BNF) in agriculture and livestock breeding activities which contribute to $48 \%$ of total anthropogenic input of nitrogen to the basin, surpassing contribution from nitrogenous fertilisers (38\%) and from depositions of nitrogen due to human activities (14\%) and imported food and raw material $(\sim 0 \%)$.

Results detailing human sources of reactive nitrogen to the environment are useful to point out the importance of nitrogen from agriculture and livestock breeding sectors playing a decisive role in BLPB, since it would provide about $86 \%$ of total anthropogenic input to the BLPB, mainly due to BNF in soybean production and fertiliser application in corn, coffee and sugarcane fields. Figure 4 ranks the main nitrogen inputs to BLPB by type of crops, including silviculture and agriculture and livestock breeding activities.

We also estimate fertiliser application in each portion of the states belonging to the basin allowing a brief overview of the association between fertiliser use and the political borders. Considering contributions from chemical fertiliser to produce cotton, rice, wheat, oranges, beans, sugarcane, coffee, and corn but disregarding inputs from soybean and pasture BNF, it was possible to estimate an average nitrogen application in kilogrammes per fertilised hectare in each state.

The estimated values in Table 1 highlight the states of São Paulo, Paraná and Minas Gerais with the largest fertilised areas, while Goias, Mato Grosso and Distrito Federal comprise the smallest fertilised areas in BLPB. Due to different land-uses in states, the average fertiliser use per area is relatively higher in Minas Gerais (177 kg N. $\mathrm{ha}^{-1} \cdot \mathrm{yr}^{-1}$ at the southern portion belonging to the basin)

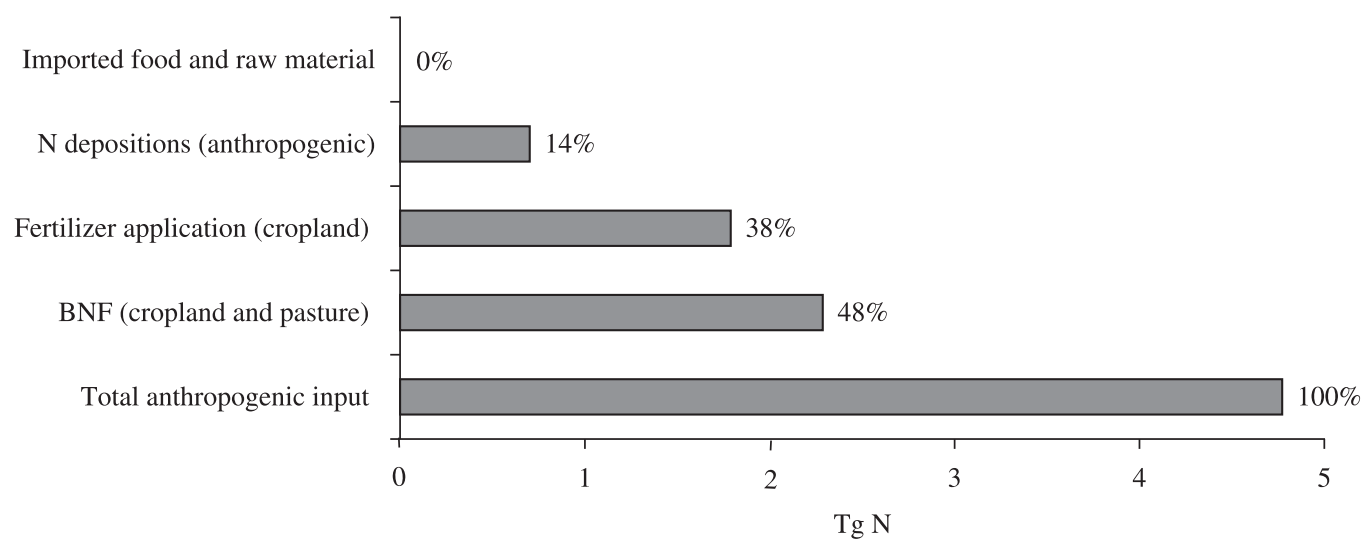

Figure 3. Estimate of annual anthropogenic inputs of nitrogen to Brazilian La Plata basin (values in Tg N.yr ${ }^{-1}$, baseline 2002), assuming BLPB as self-sufficient in terms of nitrogen. 
probably because of the large proportional area cultivated with coffee, which receives greater amounts of nitrogen fertiliser when compared to other crops. Rio Grande do Sul state, which mainly fertilises rice and wheat fields, had the lowest average application intensity relative to other states (Table 1).

\subsection{Nitrogen exports from $B L P B$}

\subsubsection{Riverine export}

Filoso et al. (2006) estimated an export of $0.14 \mathrm{Tg}$ of dissolved inorganic nitrogen (DIN) by the Paraná River - the collection point was close to the Brazil-Argentina border. Assuming that the export of DIN in tropical rivers is about two-thirds that of total N, they calculated the export of $\mathrm{N}$ in the Parana River at the Brazilian border amounts to 0.21 Tg N.yr-1 . Based on Lewis et al. (1999) they also calculated Brazilian riverine $\mathrm{N}$ exports through the Paraguay river as no more than about $0.03 \mathrm{Tg} \mathrm{N} . \mathrm{yr}^{-1}$.

Contributions of riverine export originated in Brazilian lands to the Uruguay River basin are difficult to obtain. Outside Brazilian lands, the total nitrogen in areas of higher organic pollution are downstream from the cities and industrial centres such as Salto-Concórdia, PaysanduColón and the mouth of the Gualeguaychú River averaging $336 \mathrm{mg} . \mathrm{L}^{-1}$ and $941 \mathrm{mg} . \mathrm{L}^{-1}$ (maximum of 5,430 mg/L) due to the release of domestic and industrial sewage (CARU, 1993). However we assumed average values of

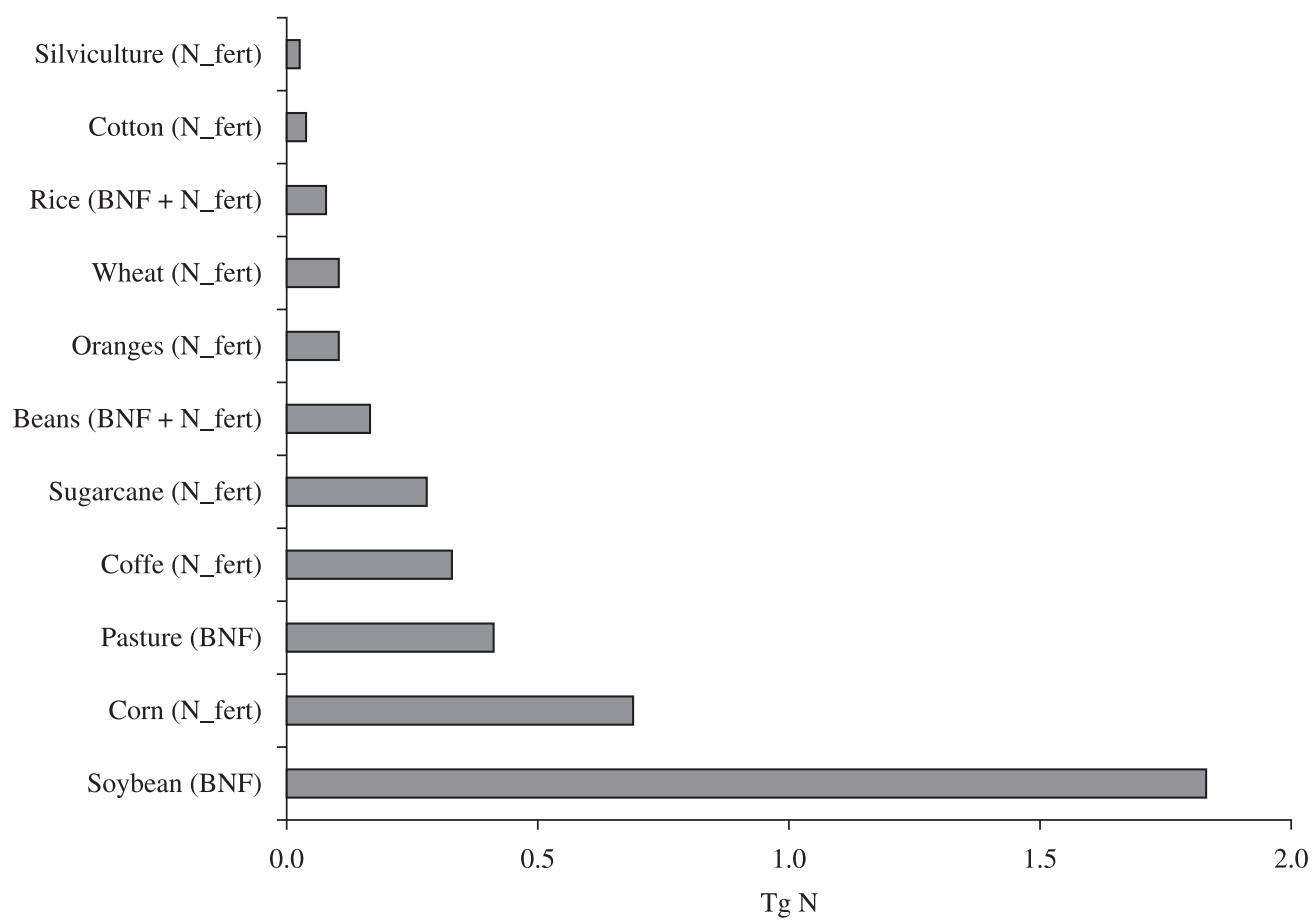

Figure 4. Main agriculture and livestock breeding inputs to BLPB derived from biological nitrogen fixation (BNF) and nitrogen chemical fertilisation (N_fert), given in Tg N...yr ${ }^{-1}$, baseline of 2002.

Table 1. Estimate of cropland area, total nitrogen use in cropland and average fertiliser use in each one of the states belonging to BLPB.

\begin{tabular}{|c|c|c|c|}
\hline State & $\begin{array}{l}\text { Cropland area inside } \\
\text { BLPB }\left(\times 10^{3} \text { ha }\right)\end{array}$ & $\begin{array}{l}\text { Total fertiliser input in } \\
\text { cropland area ( } \mathrm{Tg} \mathrm{N} . \mathrm{yr}^{-1} \text { ) }\end{array}$ & $\begin{array}{c}\text { Average fertiliser use in } \\
\text { cropland }\left(\mathrm{kg} \mathrm{N}^{\mathrm{n}} \mathrm{ha}^{-1}\right)\end{array}$ \\
\hline São Paulo & 4,869 & 0.52 & 106 \\
\hline Paraná & 4,774 & 0.46 & 96 \\
\hline Minas Gerais & 1,920 & 0.34 & 177 \\
\hline Rio Grande do Sul & 1,428 & 0.12 & 85 \\
\hline Mato Grosso do Sul & 1,024 & 0.09 & 93 \\
\hline Santa Catarina & 1,007 & 0.10 & 101 \\
\hline Goiás & 1,000 & 0.09 & 100 \\
\hline Mato Grosso & 487 & 0.05 & 102 \\
\hline Distrito Federal (Brasília) & 50 & 0.05 & 112 \\
\hline Total BLPB & 16,559 & 1.79 & 108 \\
\hline
\end{tabular}


particulate organic nitrogen (PON), DIN and dissolved organic nitrogen (DON) considered in simulations of Huret et al. (2005) when they simulated nitrogen supply to La Plata River. Summing PON, DIN and DON, average total nitrogen (TN) concentration in this river will be around $1.1 \mathrm{mg} . \mathrm{L}^{-1}$. Considering average annual discharge of $4040 \mathrm{~m}^{3} . \mathrm{s}^{-1}$ of the Uruguay River in Brazilian territory (Braga et al. 1998), Brazilian riverine export to Uruguay River could reach $0.14 \mathrm{Tg} \cdot \mathrm{yr}^{-1}$. Considering the sum of nitrogen riverine exports from the Paraná, Paraguay and Uruguay rivers, we estimate a value of $0.38 \mathrm{Tg}_{\mathrm{gr}} \mathrm{yr}^{-1}$ of nitrogen exported by BLPB.

\subsubsection{Agriculture and livestock breeding products}

Assuming BLPB playing a role of an exporter basin, the gathered data indicates soybean, soy meal, beef, pork and poultry as major commodities with high nitrogen content and significant export trades. To calculate soybean production, we considered Brazilian mean productivity of $2,800 \mathrm{~kg} \cdot \mathrm{ha}^{-1}$ and average export of $38 \%$ of all soybean harvested in 2002/2003; soy meal exported is equivalent to $26 \%$ of all soybean harvested in terms of mass (FNP, 2006). Therefore, multiplying soybean area, productivity and average export values, soybean and soy meal are related to exports of 0.61 and $0.45 \mathrm{Tg} \mathrm{N} . \mathrm{yr}^{-1}$, respectively, as represented in Figure 5.

Calculations of beef exports were based on the total production in every state in the BLPB (Igreja et al., 2006) and the average Brazilian beef export rate of $13 \%$ in 2002/2003. In the case of states not fully inserted in the $\mathrm{BLPB}$, only the fraction of the production inside the BLPB

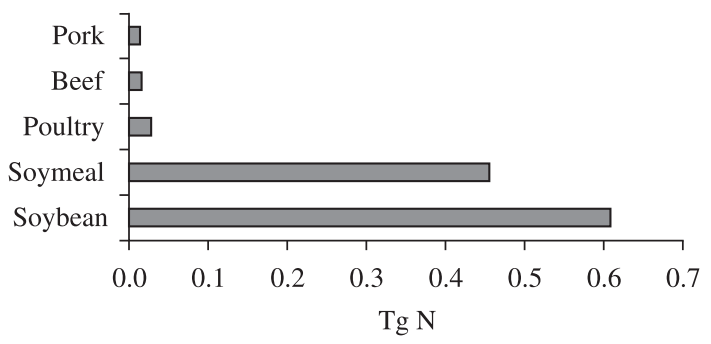

Figure 5. Average exports of nitrogen from agricultural products from Brazilian La Plata basin to external markets in the year of 2002 . was considered assuming the cattle livestock distribution in Brazil. Total nitrogen exported as beef is about $0.016 \mathrm{Tg}$. $\mathrm{yr}^{-1}$. Exports of pork and poultry were obtained summing all the state's exports (ABIPECS, 2002; ABEF, 2002), also considering the fraction of pig and chicken livestock in the basin. Therefore, total nitrogen exports were 0.014 and $0.027 \mathrm{Tg} . \mathrm{yr}^{-1}$, respectively. According to results in this paper, nitrogen exports of poultry are greater than beef and pork. However, soybean and soy meal exports (soybean oil was ignored due to its negligible protein content) are still related to the major agropecuary nitrogen exports of BLPB. Figure 6 presents riverine and agricultural exports of nitrogen in BLPB that would be approximately $1.5 \mathrm{Tg}$ in the year of 2002. Total agricultural export reaches 1.12 ( $75 \%$ of total) and riverine $0.38 \mathrm{Tg} \cdot \mathrm{yr}^{-1}$ (25\% of total).

According to the map (Figure 1) from Embrapa Agropecuária Informática, BLPB total area is around $1,405,000 \mathrm{~km}^{2}$. In terms of nitrogen input and output per area, total anthropogenic nitrogen input flow is $3,392 \mathrm{~kg} \mathrm{~N} . \mathrm{km}^{-2}$. $\mathrm{yr}^{-1}$ considering BNF, chemical fertiliser and atmospheric depositions. We could also subtract this number of agricultural exports, obtaining $2595 \mathrm{~kg} \mathrm{~N} \cdot \mathrm{km}^{-2}$. $\mathrm{yr}^{-1}$. On the other hand, summing up nitrogen riverine and agricultural exports, the total output is $1,067 \mathrm{~kg} \mathrm{~N} \cdot \mathrm{km}^{-2} \cdot \mathrm{yr}^{-1}$ which is near to $30 \%$ of the anthropogenic input. Separately, riverine export per area is $271 \mathrm{~kg} \mathrm{~N} \cdot \mathrm{km}^{-2} . \mathrm{yr}^{-1}$ which represents only $8 \%$ of total anthropogenic input. The main export of nitrogen in BLPB is clearly soybean and soy meal trade to markets outside the basin which represents 756 of the total $797 \mathrm{~kg} \mathrm{~N}$. $\mathrm{km}^{-2} \cdot \mathrm{yr}^{-1}$. Table 2 summarises anthropogenic inputs and outputs, taking into account material flows $\left(\mathrm{Tg} \cdot \mathrm{yr}^{-1}\right)$ and nitrogen flow per area $\left(\mathrm{kg} \mathrm{N} \cdot \mathrm{km}^{-2} \cdot \mathrm{yr}^{-1}\right)$ of 2002.

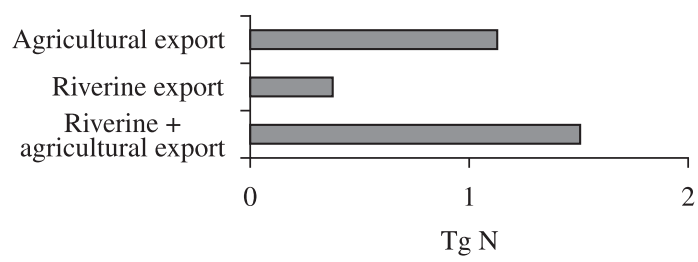

Figure 6. Riverine and agricultural exports of nitrogen in Brazilian La Plata basin in 2002 calculated in this paper, values in terms of $\mathrm{Tg}$ of nitrogen per year.

Table 2. Anthropogenic sources and nitrogen outputs in Brazilian La Plata river basin

\begin{tabular}{|c|c|c|}
\hline Brazilian La Plata basin & $\begin{array}{c}\text { Total nitrogen flow } \\
\text { Tg N.yr-1 } \\
\end{array}$ & $\begin{array}{l}\text { Flow per area } \\
\text { kg N.km-2 } \mathrm{yr}^{-1}\end{array}$ \\
\hline${ }^{a}$ Anthropogenic input & 4.77 & 3392 \\
\hline Agriculture and livestock breeding BNF & 2.29 & 1627 \\
\hline Fertiliser application & 1.79 & 1274 \\
\hline Anthropogenic deposition & 0.69 & 491 \\
\hline Nitrogen outputs & 1.50 & 1067 \\
\hline Agricultural export & 1.12 & 797 \\
\hline Riverine export & 0.38 & 271 \\
\hline
\end{tabular}

${ }^{a}$ Net anthropogenic input could also be calculated by subtracting agricultural exports, obtaining $3392-797=2595 \mathrm{kgN}$. $\mathrm{km}^{-2} \cdot \mathrm{yr}^{-1}$. One teragram of nitrogen $(\mathrm{TgN})=10^{12} \mathrm{~g} . \mathrm{N}$. 
Considering the spatial scale of BLPB, it is possible to compare values of nitrogen flows under human influence obtained in this paper with data from Howarth et al. (1996) who grouped mean values of nitrogen inputs and outputs of North American, South American, Central American and European great river basins. With the aim of comprehending how intense human intervention is in the BLPB, Table 3 presents values of flows at North Atlantic watersheds. In terms of territorial magnitude, BLPB is similar to NW plus SW European basins and also to NE and SW coast basins of US.

Anthropogenic depositions in BLPB are close to SW European behaviour and are quite distant from patterns observed in South America, represented by the Amazon and Tocantins basins. The application of chemical fertiliser in BLPB (around 1,200 $\mathrm{kg} \mathrm{N} . \mathrm{km}^{-2}$ ) is similar to the southeastern coast of US and leguminous BNF in BLPB is only comparable to leguminous crop fixation in the Mississippi river basin which occupies 3.23 million $\mathrm{km}^{2}$ of the US. Although BLPB is about half of Mississippi river basin, they are pretty similar in terms of anthropogenic deposition, nitrogen chemical fertilization and also have the characteristic of nitrogen exporter of food and feed.

In terms of total riverine export from the BLPB, our estimative of $271 \mathrm{~kg} \mathrm{~N} \cdot \mathrm{km}^{-2}$ is low compared to North Atlantic watersheds. Observing Howarth et al. (1996), whose model correlates net anthropogenic inputs and riverine export, BLPB behaviour would not fit to their curve because it is similar to the SW European coast basin, which has low riverine export compared to the high rate of anthropogenic inputs of nitrogen. Considering the data of riverine export of Paraná and Paraguay basins were based on Filoso et al. (2006) who calculated values of riverine export according to Bonetto et al. (1991) and Lewis et al. (1999), it is possible that the lack of up-to-date data of total nitrogen in rivers within the BLPB increases uncertainties (possibly underestimation) of the actual value nitrogen exports through the Paraná and Paraguay rivers.

Nonetheless, the BLBP's riverine export of nitrogen is in accordance with values observed when the nitrogen export by La Plata River near Buenos Aires, Argentina, is accounted. Huret et al. (2005) describes average total nitrogen (TN) concentration of $1.1 \mathrm{mg} . \mathrm{L}^{-1}$ in La Plata River and a mean discharge of $22,000 \mathrm{~m}^{3} \cdot \mathrm{s}^{-1}$. Combining these values indicates an average riverine export of $0.76 \mathrm{Tg} \cdot \mathrm{yr}^{-1}$. Considering the total area of La Plata basin - 3,100,000 $\mathrm{km}^{2}$ - an average of $246 \mathrm{~kg} \mathrm{~N} . \mathrm{km}^{-2} \cdot \mathrm{yr}^{-1}$ would be related to riverine export of nitrogen.

\section{Discussion}

\subsection{Climate change and the nitrogen cycle in $B L P B$}

The results reveal that only a fraction of total anthropogenic nitrogen input to the BLPB is exported to rivers and also traded as commodities. However, the remaining anthropogenic nitrogen input - about $69 \%$ - might have other fates. Figure 7 represents four possible routes of remaining nitrogen: 1) denitrification in terrestrial soils;
2) volatilisation in terrestrial soils; 3 ) denitrification in freshwater systems; 4) leaching to groundwater storages; 5) absorption of riverine nitrogen by riparian biomass. Liu et al. (2010) consider that $55 \%$ of the global nitrogen outputs of terrestrial systems are uptake by harvested crops (35\%) and crop residues (20\%), losses by leaching is related to $16 \%$, soil erosion to $15 \%$ and gaseous emission to $14 \%$ of total output. According to Smil (1998), most of the nitrogen introduced in global agroecosystems is further distributed as reactive $\mathrm{N}$ to other systems: $50 \%$ as harvested crop, $23 \%$ as leached nitrogen, $6 \%$ as volatilised ammonia, $6 \%$ as volatilised $\mathrm{NO}_{\mathrm{y}}$ and $\mathrm{N}_{2} \mathrm{O}$, and only $10 \%$ is converted to unreactive $\mathrm{N}_{2}$ by denitrification in the agroecosystem. According to Gruber and Galloway (2008), about half of global terrestrial denitrification takes place in freshwater systems, with most of the reactive nitrogen that is denitrified coming from the land. As observed in the results of this paper, their assessment of global nitrogen cycle indicates that most of the land-derived reactive nitrogen is removed, leaving a comparatively small flux of reactive nitrogen entering the ocean. Nitrous oxide derived from denitrification would represent a positive feedback to climate change (see Figure 7).

Indeed, Gruber and Galloway (2008) affirm that global climate has been affected by many changes over the past 60,000 years and $\mathrm{N}_{2} \mathrm{O}$ is related to relatively quick changes that are synchronised with climate variations in the past. Coincidentally or not, cold periods generally corresponded to low $\mathrm{N}_{2} \mathrm{O}$ concentrations, and vice versa. Nonetheless, according to their study the response of $\mathrm{N}_{2} \mathrm{O}$ to such modifications in climate conditions was not linear but it is characterised by hysteresis and enhanced responses to prolonged climatic perturbations.

Considering the connection of $\mathrm{N}_{2} \mathrm{O}$ emission and the climate system, it is reasonable to assume that denitrification processes in terrestrial and aquatic ecosystems of BLPB represents a potential threat to the climate system - given that at least a fraction of the $69 \%$ total anthropogenic inputs would undergo denitrification which might contribute to global warming. Even if we could estimate the quantity of $\mathrm{N}_{2} \mathrm{O}$ released to the entire climate system, the emission would not be related to linear effects of global temperature and precipitation (Gruber and Galloway, 2008).

Anthropogenic inputs of reactive nitrogen to a river basin might also disturb the terrestrial ecosystem and cause eutrophication - and phytoplankton blooms - in coastal zones, affecting global climate due to ocean fertilisation. Nagy et al. (2002) suggest that increasing nutrient loads of nitrogen and phosphorus and the low potential to dilute nutrients by La Plata River may aggravate eutrophication conditions like oxygen stress and harmful blooms in coastal zones. Ocean fertilisation might reduce global warming effects due to increased biomass production in marine ecosystems. On the other hand, an increasing dissolved $\mathrm{CO}_{2}$ reduces ocean $\mathrm{pH}$ overtime due to additional formation of carbonic acid on the ocean surface which represents a threat to shell-forming organisms and decreases coral calcification (Hoegh-Guldberg et al., 2007), decreasing the 
potential of pelagic systems to capture and store carbon. Warming has also been related to altering the functioning and biogeochemistry of shallow pelagic ecosystems, further reducing their potential for carbon sequestration (Hoegh-Guldberg and Bruno, 2010).

According to Canadell et al. (2007), the terrestrial nitrogen cycle has the potential to interact with terrestrial carbon cycle responses to changes in climate, nitrogen inputs and land use. However it is difficult to measure the contribution of human-altered nitrogen cycle in BLPB to global - or regional - climate change. On the other hand, two possible interactions between $\mathrm{N}$-cycle and climate change may happen: the first one is related to the terrestrial nitrogen cycle affecting climate (represented in Figure 7) and the second would be the opposite situation. Perhaps both interferences are simultaneous and affect each other providing non-linear effects to global climate system and to biogeochemical cycles in BLPB.

\subsection{Effects of climate change on nitrogen flows in $B L P B$.}

Climate change is also affecting biogeochemical cycles in BLPB. According to the IPCC Special Report on Emissions Scenarios (SRES), there are four main scenarios for emissions related to climate change: A1, A2, B1 and B2 describe the relationship between forces driving greenhouse gases and aerosol emissions during the $21^{\text {st }}$ century for large world regions and globally. We will highlight in this paper the A2 scenario which indicates a very heterogeneous world with continuously increasing global population and regionally oriented economic growth, more fragmented and slower than other scenarios (i.e., "business as usual" emissions scenario); and also B2 which represents a world which give emphasis to local solutions to economic, social and environmental sustainability, with continuously increasing population (lower than A2) and intermediate economic development (IPCC, 2000).

Regarding the impact of climate change in BLPB, international initiatives such as the Europe South America Network for Climate Change Assessment and Impact Studies - CLARIS LPB project (www.claris-eu.org) - and publications of Marengo et al. (2012) identified climate and hydrological processes disturbing La Plata Basin. For instance, the effect of climate change and South American Monsoon System (SAMS) affecting upper Basins of Parana-La Plata through rainfall anomalies. Additionally, Soares and Marengo (2008) describe the tendency of intensification of the South American Low Level Jet (SALLJ) in both IPCC A2 and B2 scenarios that will provide larger and faster moisture flux between Amazonia and La Plata Basin, forcing the development of storms and more frequent and intense extreme rainfall events in southern and southeastern Brazil.

Based on results of nine models from the CMP3 - Coupled Model Intercomparison Project version 3 - from Seth et al. (2010) to examine projected changes of seasonal South American Monsoon System for 2070-2100 considering the A2 (business as usual) scenario, we assumed the Monsoon system (MN) is influencing the Upper Paraguay basin, South Atlantic Convergence Zone (SACZ) affecting Upper Paraná and Southeastern South America (SESA) is related to Lower BLPB. According to Seth et al. (2010), there will be a small increase in precipitation during the later rainy season (Feb-Apr) in the Monsoon region - Upper Paraguay - however there disagreement among their models. During the dry season (May-Aug), negative changes of daily precipitation are small but significant, with agreement among the models. During the SAMS onset period, there will be a $15 \%$ decrease in precipitation in October. Regarding their predictions for temperature, the model simulates a warming from $3-5^{\circ} \mathrm{C}$, with the major increases during spring (Oct-Dec) and lowest increases during late rainy season.

Regarding Upper Parana basin - under the influence of $\mathrm{CSACZ}$-, changes are similar to Upper Paraguay region, i.e., the models predict little increase in precipitation from February to April and significant drying during the early rainy season from September to November: $-14,-8$ and $-5 \%$, respectively. Concerning temperature, there will be little temperature increases in Upper Parana due to its proximity to the coast. Mean temperature values in CSACZ will increase from $3-4{ }^{\circ} \mathrm{C}$ according to the A2 scenario, peaking in November.

On the other hand, the Lower BLPB (SESA) will face increases in precipitation during much of the year, with major increases during the rainy season from October to February. Moreover, Seth et al. (2010) highlight significant increases in the mean during the first half of the season: $11 \%$ on October, $17 \%$ on November, $9 \%$ on December and $6 \%$ on January. Similarly to other regions of BLPB, there will be increases in temperature ranging from $2-4{ }^{\circ} \mathrm{C}$, peaking in the winter months.

In summary, in case scenario A2 prevails, the BLPB will face periods of increased or decreased precipitation during its rainy season, diminished precipitation during dry seasons, and increased mean temperature $\left(2-5^{\circ} \mathrm{C}\right)$ in the period of 2070-2100. These phenomena will indeed affect the nitrogen cycle in the BLPB, since changes in the local hydrological cycle, temperature and consequent land-use change can alter the rates of nitrogen inputs and outputs observed in the basin.

Galloway et al. (2004) observe that wetter and warmer climates can lead to higher rates of nitrogen mineralisation to atmospheric and aquatic environments. Considering also that nitrogen usually is not the limiting nutrient in tropical ecosystems (Martinelli et al., 1999), a rise in anthropogenic nitrogen inputs could promote fast increases in nitrogen losses to air and water (Matson et al., 1999). Although there are many environmental drivers affecting denitrification, Attard et al. (2010) verified that soil moisture explains a more substantial part of the variation in potential denitrification in grassland systems submitted to global change components. Therefore, it is reasonable to assume that higher temperatures and increases in precipitation during the rainy season - when most fertiliser application occurs - will affect decomposing and transporting 
processes in BLPB. Considering Galloway et al. (2004) and Attard et al. (2010), we suppose that an augmented nitrogen loss through denitrification is expected over the period 2070-2100 in scenario A2 in BLPB, especially in lower BLPB where increases in precipitation during much of the year are anticipated in CMP3 models.

The study of climate change affecting the process of biological nitrogen fixation in tropical regions is scarce. However Lazzarotto et al. (2010) developed climate scenarios projecting rising temperatures, high $\mathrm{CO}_{2}$ concentration in the atmosphere and extended drought periods during late spring, summer and early autumn in an unfertilised grassland (grass and clover) sward on the Swiss Plateau. They observed an overall positive response of BNF to high $\mathrm{CO}_{2}$ levels. Climate change alone did not restrain biological nitrogen fixation, however this additional input from symbiotic BNF was not enough to improve the mineral nitrogen status of the system. Unfortunately, such a regional study is not applicable for the BLPB since there are different environmental circumstances affecting the basin and moreover, Lazzarotto et al. (2010) state that changes in plant, soil microbial biomass activity and soil organisms could significantly alter the ecosystem responses to the effects of climate change.

\subsection{Climate change and land-use change in BLPB.}

In order to anticipate possible implications of climate change on biological nitrogen fixation, we will focus on land-use change related to soybean, which provides most of the BNF in the BLPB. Despite the behaviour of BNF under climate change conditions, increases of temperature will limit the yield of crops. In projections of Nobre et al. (2005) highlight increasing temperature as a potential driver of change in suitable areas for crops in Brazil, including soybean. They point to an average reduction in Brazil of up to $60 \%$ in the suitable area due to a $5.8{ }^{\circ} \mathrm{C}$ temperature increase, if farmers keep their planting calendar starting in November. According to their projections, most of this impact would take place in the southern region (Paraná, Santa Catarina and Rio Grande do Sul states) which corresponds to the lower BLPB. Furthermore, Zullo Junior et al. (2008) point out temperature increases of 1,3 and $5.8{ }^{\circ} \mathrm{C}$ decreasing the suitable area for soybean cultivation in Mato Grosso state by 5,29 and $63 \%$, respectively. In the case of Paraná state, the impact of climate change would be higher because forecasts point to the same temperature changes decreasing the suitable area by 27,78 and $93 \%$, respectively.

According to the maps above (see Figure 8), the climate change scenario is able to diminish suitable area for soybean in BLPB. Considering the range of $2-5^{\circ} \mathrm{C}$ (Seth et al., 2010) or an average $3{ }^{\circ} \mathrm{C}$ of temperature increase for 2070-2100, suitable area contraction in BLPB will involve many states: southern Mato Grosso, central Mato Grosso do Sul, southern Goiás, central and western São Paulo, southern Minas Gerais, northern Paraná, western Santa Catarina, and entire Rio Grande do Sul. According to Zullo Junior et al. (2008), although there will be an increase of precipitation in most of the country, higher temperatures during the flowering stage will promote the abortion of flowers and therefore, decrease in productivity.

Consequently, biological nitrogen fixation may be affected (probably reduced in case farmers follow the recommendations in the maps of climate risks zoning), since the substitution involving other crops or pasture would decrease BNF rates compared with soybean. This assumption disregards a future scenario with new soybean varieties resistant to extreme events of climate change and is not related to changes in current soybean planting calendar.

In case of pasture BNF, data is scarce but Assad et al. (2008) highlight $25 \%$ decrease in cattle grazing capacity due to climate change. They point out an average temperature increase of $3{ }^{\circ} \mathrm{C}$ up to 2100 and the consequent loss of suitable areas for pasture and decline of meat exports due to the enlargement of dry season in current pasture land (additional 30 to 50 dry days). They don't provide further details regarding pastures in BLPB; however we assume that a negative impact in grazing capacity wouldn't positively affect BNF input in the basin.

On the other hand, other crops will expand its overall area under future climate change scenarios. Assad et al. (2008) highlight the migration of sugarcane and manioc areas to southern Brazil due to the increase of unsuitable areas in the northeastern region. Regarding sugarcane, areas with low climatic risk will occupy central and southern Brazil - especially Rio Grande do Sul State, partially inserted in BLPB. The total area in the country will increase from 6 to 13 million ha in 2070 considering the A2 scenario, and reaches 15 million taking into consideration B2 scenario. According to Assad et al. (2008), most sugarcane will expand toward areas of degraded pastures - current 100 million ha.

Since it is difficult to account the complete nitrogen balance in BLPB, our assumptions regarding climate change scenarios will be limited to changes of proportions of nitrogen flows in relation to human-derived inputs and outputs. In other words, Table 4 presents the change in the profile of the anthropogenic nitrogen cycle but doesn't describe quantitative changes in flows. We assumed qualitative effects of climate change on anthropogenic $\mathrm{N}$-cycle would be pretty similar in both A2 and B2 scenarios, although flows are assumed to be different in absolute terms (i.e., $\left.\mathrm{kg} \mathrm{N} \cdot \mathrm{ha}^{-1} \cdot \mathrm{yr}^{-1}\right)$.

Considering the land-use change scenarios (Nobre et al., 2005; Zullo Junior et al., 2008), we assumed soybean competing with other nitrogen-fertilised crops, since growing population inside and outside BLPB will demand for more food, energy and raw material. In case farmers follow the recommendations of climate risks zoning, the proportion of BNF in the total anthropogenic input tends to decline in 2070-2100 compared with 2002. Regarding the A2 scenario, a higher fertiliser use (whether compared with B2) would increase productivity and also losses related to nitrogen leaching in BLPB - i.e., nitrate flows to underground storages during the rainy season -, denitrification to $\mathrm{N}_{2} \mathrm{O}$ and $\mathrm{N}_{2}$, and volatilisation of ammonia. This assumption is 
based on studies detailing different fates of human-derived nitrogen in global scale (Liu et al., 2010; Smil, 1998).

As shown in Table 4, scenario A2 and B2 are similar despite the difference in the contribution of atmospheric deposition and gaseous losses to the total anthropogenic outputs. Regarding B2 scenario, we assumed a reduction in nitrogen gaseous emissions from biomass burning (due to low or zero elimination of native vegetation, abolition of foliage burning before sugarcane harvest and adoption of no-tillage practices) and identical fossil fuel combustion and denitrification compared to the proportion in 2002. Considering this optimistic scenario (B2) for 2070-2100, the entrances from atmospheric depositions to the total human inputs are also assumed to be similar to the proportion observed in 2002. According to Galloway et al. (2004), rates of riverine reactive $\mathrm{N}(\mathrm{Nr})$ discharges to coastal zones on a global scale tend to increase from $47.8 \mathrm{Tg}$ in the early 1990 's to $63.2 \mathrm{TgN}$ in 2050 due to Haber-Bosch, BNF-cultivation and fossil fuel combustion. However, they predict smaller increase in global riverine export compared with the raise of atmospheric emission fluxes in 2050. Galloway et al. (2004) explain the reasons for relatively limited response of riverine systems to increases in $\mathrm{Nr}$ creation rate: probably the ability of terrestrial systems to accumulate $\mathrm{Nr}$ and denitrification processes in terrestrial systems or in the stream/river continuum prior to transport to the coast. We can also assume an enhanced flow of nitrogen riverine export in BLPB $\left(\mathrm{Tg}_{\mathrm{gr}} \mathrm{yr}^{-1}\right)$ however it is difficult to affirm whether such riverine export will decrease or increase its proportion in relation to the sum of all anthropogenic outputs.

Although exports of agricultural products might increase in the period of 2070-2100 due to continuous growing population described in A2 and B2 scenarios, most of them are related to smaller protein contents compared with soybean-related products. Therefore, nitrogen exported within agricultural products tends to proportionally decline in relation to other anthropogenic inputs. For instance, in case we observe sugarcane expansion over degraded pasture or soybean areas in the period of 2070-2100, ethanol and sugar sold to external markets will represent a significant increase in terms of carbon exports; however nitrogen in foliage and stalk are comparatively available in small quantities (compared with soybean) and would be partially stored in the soil or burnt in sugarcane mills in order to generate electricity - maybe contributing to increase atmospheric emissions of reactive nitrogen.

Observing Table 4, the profile of anthropogenic nitrogen cycle in BLPB will be characterised by increasing shares of nitrogen coming from fertiliser and decreasing shares of biologically fixed nitrogen; the outputs will be related to increasing shares of nitrogen losses to atmosphere and groundwater, and the share of exported nitrogen within agricultural products tend to decrease.

\subsection{Disturbance of nitrogen cycle and implications to the ecosystem services}

According to MEA (2005), biogeochemical cycles are coupled to the environmental capacity of providing goods and services to humanity - such as food, clean water, fisheries, climate regulation, waste decomposition, etc. -, therefore a perceptible consequence of anthropogenic activities in the BLBP will be related to modifications in human well-being, since impacts on economy, health, security and social relations might be perceived in the future. Jackson et al. (2008) states that the main ES affected by plant-microbe-soil nitrogen cycling would be providing services such as food and fibre production, regulating services such as waste decomposition and improvement of water quality, long-term supporting ES such as soil formation and nutrient cycling, and cultural services such as aesthetic fulfillment. Although the HaberBosch process is important to improve food production, for instance, they highlight that nearly $50 \%$ of nitrogen applied as fertiliser in global agriculture has a negative effect on regulating and supporting ES which, in turn, sustains environmental quality.

The indirect drivers of change in ES are related to demographic, economic, sociopolitical, science and technology, and cultural and religious factors; moreover, the direct drivers would be related to changes in land-use, species introduction or removal, technology adaptation and use, external inputs (such as fertiliser), harvest and resource consumption, climate change and other natural drivers (MEA, 2005). Although they are simplified, Figure 9a,b represent two scenarios that are aligned with drivers described in MEA (2005), since they consider different conditions of fertiliser application (based on Jackson et al., 2008), climate change (Seth et al. 2010) and land-use change (Nobre et al., 2005; Zullo Junior et al.,2008) affecting ES in BLPB.

The right column in Figure 9a,b point out the possible qualitative effects to the ecosystem services directly connected to the nitrogen cycle. In both scenarios, here named N-A2 and N-B2, there will be improvements in food and fibre production but damages to ecosystem services - that will be discussed further. In scenario N-A2, we assumed an emission scenario similar to IPCC's SRES $\mathrm{A} 2$, with a fast-growing population as reliant on fertiliser and fossil fuel as observed nowadays in the BLPB (year 2002), and the increasing food production is still oriented to external markets. Regarding scenario N-B2 - similarly to $\mathrm{B} 2$, population and food production will also grow during 2070-2100 but slower than N-A2; moderate fertiliser use to produce local food and low fossil fuel consumption will also provide additional $\mathrm{Nr}$ inputs to BLPB, but anthropogenic influence on the nitrogen cycle will cause lower damage to the ES when compared with tradeoffs observed in N-A2 because there will be local solutions for reducing emissions in agriculture, transport systems and energy generation.

As represented in Figure 9a,b, the main ES depleted are the air purification, climate regulation, water purification, soil formation, nutrient cycling and the biodiversity. However, other ES which are not described here can potentially be affected due to the feedback loops among ES; for instance, the loss of soil formation ES (i.e., soil 
erosion) will be related to indirect changes in ecotourism service in case we are dealing with a recreational area.

Regardless of the scenario, emissions of reactive nitrogen to the atmosphere from fertilisers, fossil fuel burning, human and livestock wastes are able to increase atmospheric pollution - i.e., to decrease air purification service - due to formation of aerosols, nitric acid, and ground-level ozone. The last reduces the air quality and contribute to respiratory diseases such as asthma (MEA, $2005)$. In case of nitrous oxide ( $\left.\mathrm{N}_{2} \mathrm{O}\right)$ emissions, Pretty et al. (2000) describe that greenhouse gases are related not only to climate change - i.e., the depletion of climate regulation service - but also to ozone layer loss in the stratosphere, which increases UV-B radiation on Earth, potentially causing increased incidence of skin cancer (MEA, 2005). Nitrous oxide, similarly to other greenhouse gases, has its climate change effects related to negative externalities associated to sea-level rise, storms, flood and drought incidence, water availability and vector-borne diseases (Pretty et al., 2000).

Anthropogenic nitrogen is also affecting water purification service, since point loads of nitrogen into terrestrial and aquatic ecosystems occasionally are not removed by natural decomposing processes. Nitrogen leaching and runoff may cause nitrate overload in some drinkable water sources in the BLPB. According to the U.S. Environmental Protection Agency (EPA, 2011), once taken into the body, nitrates are converted to nitrites which, in turn, may cause health problems or kill infants below six months who drink water containing nitrites above the maximum contaminant level. As shown in Figure 7, such local pollution is related to fertiliser leaching and livestock wastes, mineralisation of organic matter in the soil, atmospheric depositions and human sewage. As previously discussed, the overload of nitrogen and phosphorus in coastal zones may also fertilise pelagic ecosystems, both reducing oceanic $\mathrm{pH}$ and threatening shell-forming species and coral reefs (Hoegh-Guldberg et al., 2007).

Last but not least, anthropogenic interference in the BLPB will also affect the supporting ES: soil formation, nutrient cycling and biodiversity. In other words, soil erosion, loss of nutrients and extinction of species will negatively affect some sectors of the economy - such as the agricultural, fishing, cosmetics and pharmaceutical sectors, for instance; moreover, the loss of supporting services is relevant because it deals with the ecosystem infrastructure. Once it is depleted, other provisioning and regulating $\mathrm{ES}$ will no longer be provided.

Although both scenarios N-A2 and N-B2 represent losses in supporting ecosystem services, N-B2 would represent an optimistic situation in which the anthropogenic influence is still able to reverse the process of environmental degradation in order to improve the sustainability beyond the period of 2070-2100 in BLPB. According to Rockström et al. (2009), humankind has already transgressed the planetary boundary of the nitrogen cycle. Currently, human activities add roughly $150 \mathrm{Mt} . \mathrm{N}_{\mathrm{yr}} \mathrm{yr}^{-1}$; however, the limit of industrial and agricultural fixation of $\mathrm{N}_{2}$ on a global scale should be
35 Mt.N.yr ${ }^{-1}$, which is about $25 \%$ of the total amount of $\mathrm{N}_{2}$ fixed per annum naturally by terrestrial ecosystems. Therefore, such a proportion should be taken into consideration for regulating the anthropogenic inputs of nitrogen in BLPB considering scenario N-B2. In order to do so, the N-B2 scenario would be related to positive synergies and actions to conserve the ecosystem and its services. For instance, local solutions such as agroforestry could meet human needs for food and energy, restore soils and contribute to biodiversity conservation. Other strategies such as the adoption of intercropping in agriculture, the building of urban parks and other green spaces in cities, fostering of recycling urban waste into rural areas, as well as protecting natural forests and wetlands, would all decrease losses of ES. Sustainable initiatives like these are important to reverse environmental degradation because they increase carbon sequestration, water purification, flood control, wildlife habitat, waste management, among other regulating, cultural and supporting ecosystem services (MEA, 2005).

\section{Conclusion}

This first-approximation study assessed the main aspects of the nitrogen cycle in the BLPB and highlighted agricultural activities playing an important role in adding reactive nitrogen to the basin. Fortunately, most of the current anthropogenic nitrogen load in BLPB is related to BNF in soybean fields which somehow decreases the proportion of fertiliser use compared with other agricultural river basins in the world. However, future scenarios N-A2 and N-B2 for 2070-2100 may be related to increasing quantities of fertiliser use in case climate change reduces suitable areas for soybean cultivation in BLPB, benefitting fertilised crops such as sugarcane, for instance. However, scenarios N-A2 and N-B2 do not include future advances in research and development that can improve BNF varieties (of soybean or other crops) that could reduce their reliance on industrial fertilisers.

As observed in the results session, current exported nitrogen in agricultural products is higher than riverine export. Although this fact does not imply an additional load of nitrogen in BLBP, the exported protein will feed people and animals abroad (probably in Europe and Asia), then affecting their local environments through sewage and waste production. Consequently, anthropogenic disturbance is not restricted to the nitrogen cycle in BLPB but also may affect other river basins in the world as much as other countries consume such exported nitrogen. Due to the lack of data, it is important to recognize that the estimate related to agricultural exports and cultivated area in the basin was based on maps related to the distribution of crops and exports in each state. However, when there is an improvement to the database related to material flows in the BLPB, we will be able to overcome this limitation in future studies.

This conclusion also highlights that the nitrogen cycle is indirectly connected to many other ES. So, the list of ES affected by human intervention in the BLPB presented 


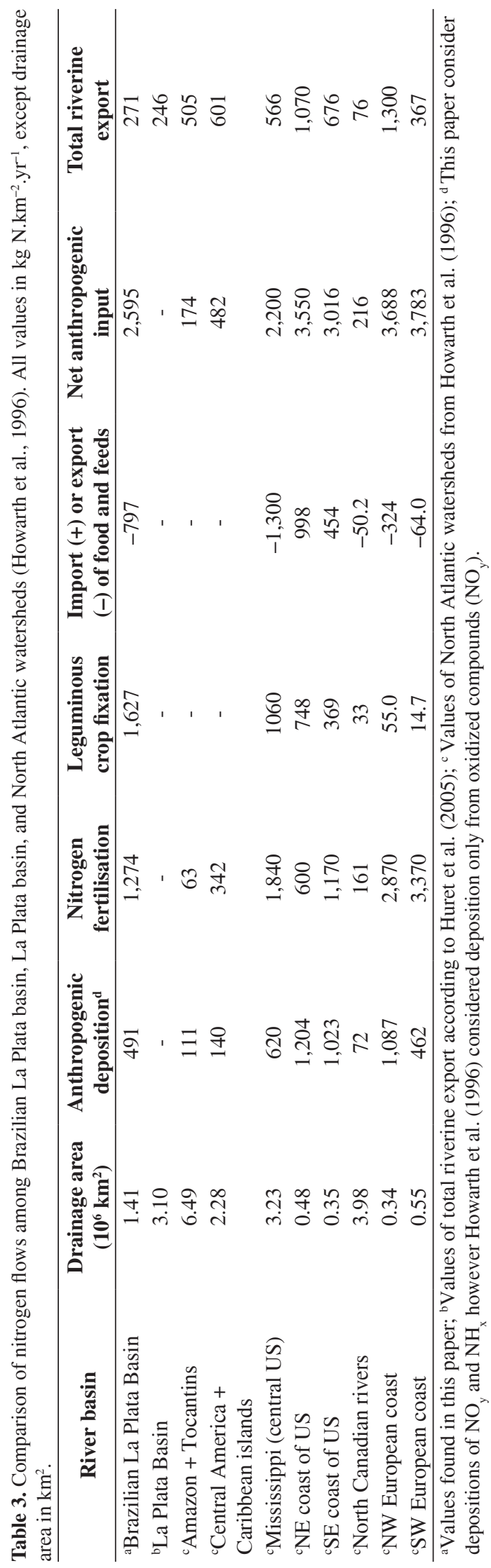




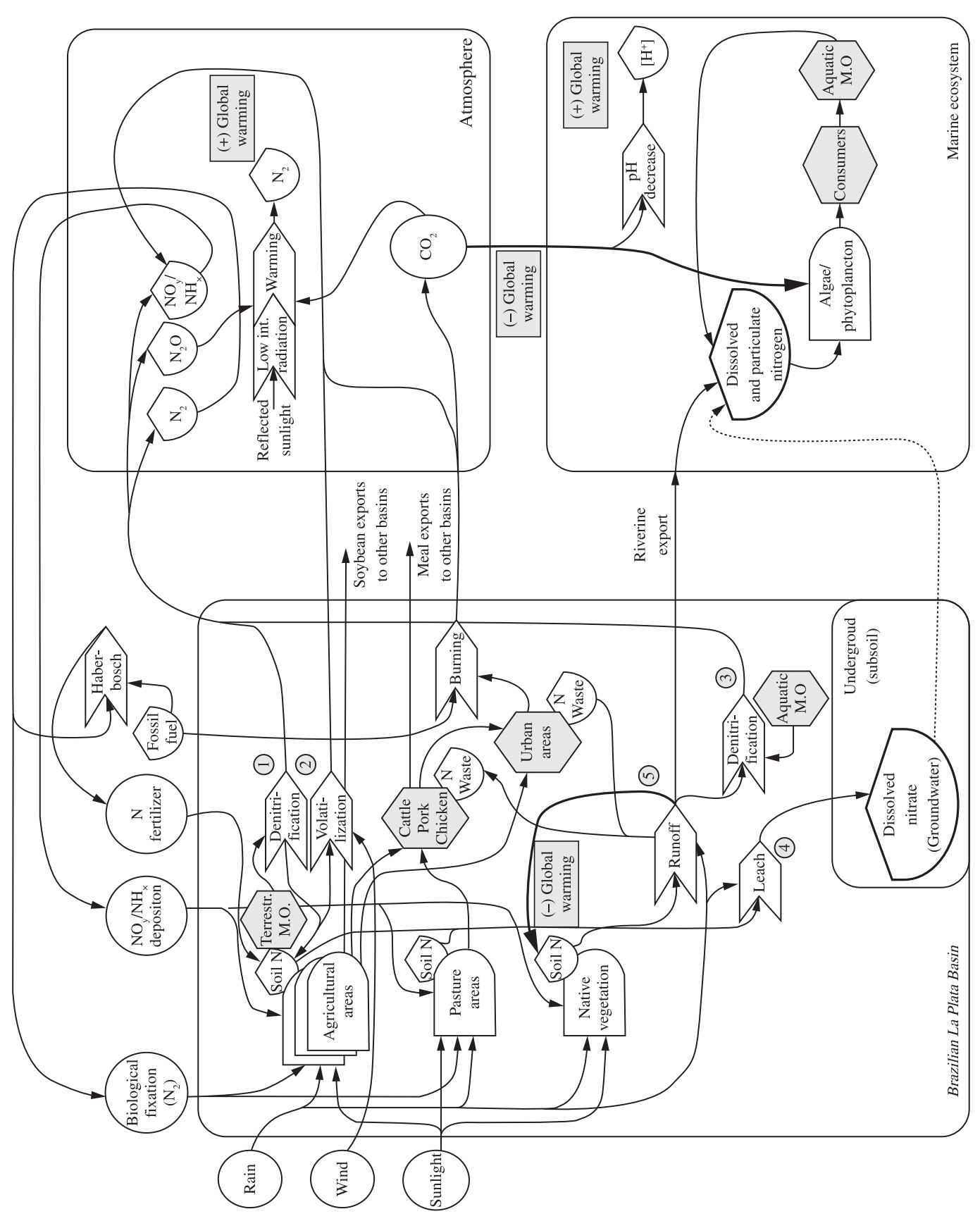

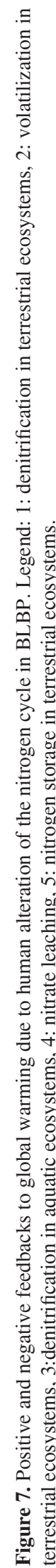



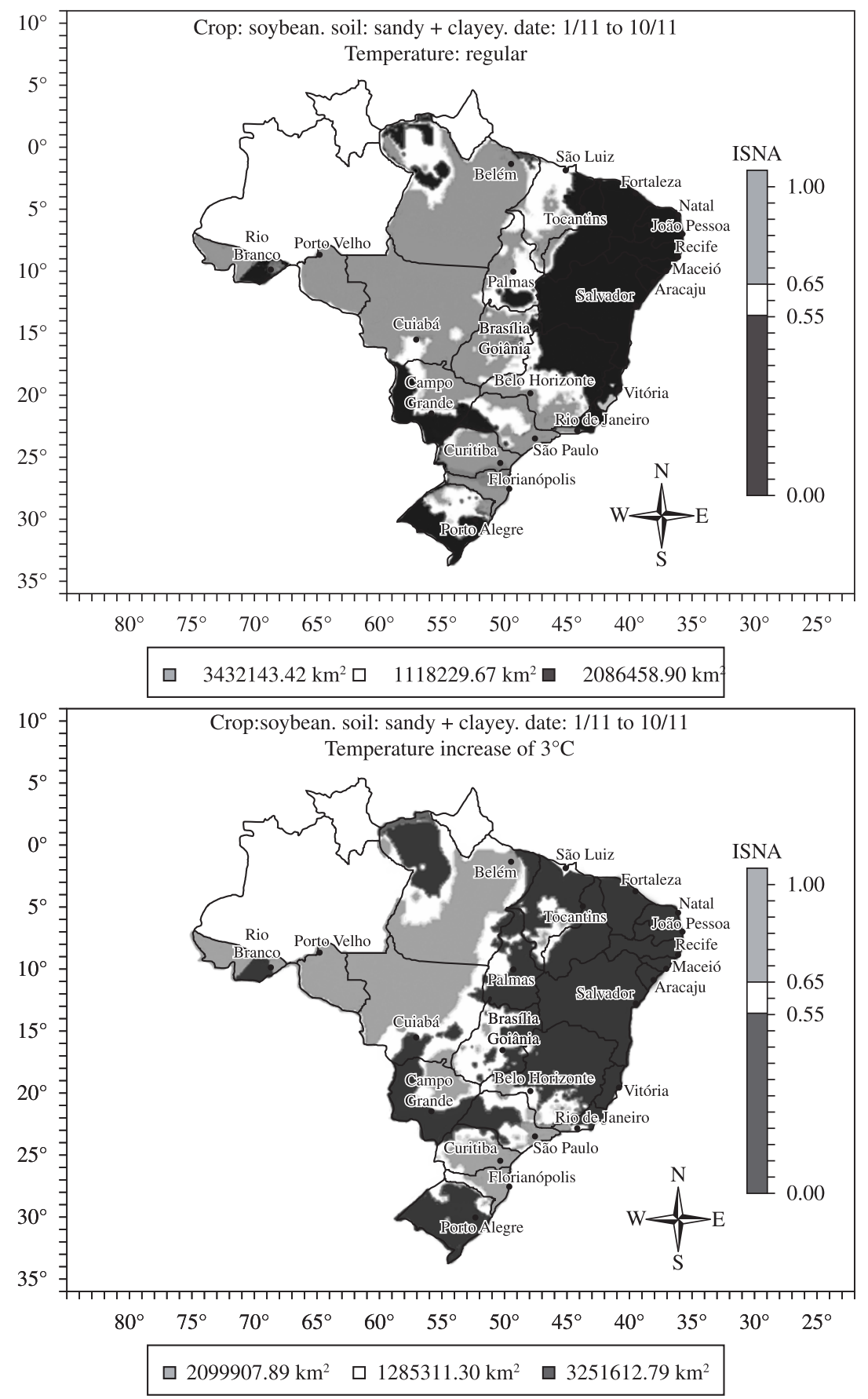

Figure 8. Impact of temperature change $\left(+3{ }^{\circ} \mathrm{C}\right)$ in suitable (grey), unsuitable (dark grey) and intermediate suitable (light grey) areas for soybean cultivation, according to maps of Embrapa-CNPTIA (Embrapa, 2010b). Source: Embrapa-CNPTIA (Embrapa, 2010b), CT-Hidro Project. Originally in red (dark grey), green (grey) and yellow (light grey).

in this paper may be larger. Moreover, feedback loops among ecosystem services should also be studied since the depletion of a given ES should impact many other ESs which, in turn, may affect other ES. The impacts of the anthropogenic nitrogen cycle to the ecosystem services should be further studied, including valuation approaches which estimate the monetary costs of increasing nitrogen load to the environment.

The information regarding N-A2 and N-B2 scenarios were presented as qualitative data. Future studies should create scenarios based on quantitative data related to fertiliser use, land-use change and climate change, etc. in order to 
Scenario N - A2

Main drivers of change
$\begin{aligned} & \text { Excessive fertilizer application } \\ & \text { Fertilized area expansion }\end{aligned}$
$\begin{aligned} & \text { Extreme rainy events (rainy } \\ & \text { season) } \\ & \text { Increasing temperature }\end{aligned}$
$\begin{aligned} & \text { Fast-growing population } \\ & \text { High sewage production } \\ & \text { High fossil fuel consumption } \\ & \text { High } \mathrm{N} \text { (and } \mathrm{P} \text { ) load in coastal } \\ & \text { zones }\end{aligned}$

(b)

Scenario N - B2

\begin{tabular}{l} 
Main drivers of change \\
$\begin{array}{l}\text { Moderate fertilizer application } \\
\text { Fertilized and } \mathrm{BNF} \text { area expansion }\end{array}$ \\
$\begin{array}{l}\text { Extreme rainy events (rainy } \\
\text { season) } \\
\text { Increasing temperature }\end{array}$ \\
\hline $\begin{array}{l}\text { Slow-growing population } \\
\text { Moderate sewage production } \\
\text { Lower fossil fuel consumption } \\
\text { Moderate (N and } \mathrm{P} \text { ) load in } \\
\text { coastal zones }\end{array}$
\end{tabular}

Figure 9. a) Anthropogenic influence on the nitrogen cycle and possible consequences to the ecosystem services in BLPB, considering N-A2 scenario; b) Anthropogenic influence on the nitrogen cycle and possible consequences to the ecosystem services in BLPB, considering N-B2 scenario.

Table 4. Proportional changes $(\Delta)$ in anthropogenic input and output in BLPB considering SRES climate change scenarios A2 and B2 for 2070-2100, compared with 2002 situation.

\begin{tabular}{lcc}
\hline \multicolumn{1}{c}{ Nitrogen inputs and outputs } & Scenario A2 & Scenario B2 \\
\hline \multicolumn{1}{c}{ ( $\Delta$ in the share of anthropogenic inputs) } & - \\
\hline Agriculture and livestock breeding BNF & - & + \\
Fertiliser application & + & 0 \\
Anthropogenic deposition & ( $\mathrm{i}$ in the share of anthropogenic outputs) & - \\
\hline Agricultural export (of nitrogen) & - & uncertain \\
Riverine export & Uncertain & 0 \\
Gaseous loss (mainly denitrification and volatilization) & + & + \\
Nitrogen leaching & + & + \\
\hline
\end{tabular}

+ proportional increase, - proportional decrease, 0: similar to the proportion observed in 2002, uncertain: uncertain proportion.

make possible predicting the marginal cost of an additional unity of nitrogen in terms of provision or depletion of the ES in BLPB. Possibly, it will be interesting to calculate the externalities related to anthropogenic nitrogen inputs in order to contribute to future policymaking oriented to the ES protection. Preferentially, future research should address the whole La Plata Basin (i.e., including contributions from
Argentina, Uruguay, Paraguay and Bolivia) in order to comprehend the anthropogenic influence on the nitrogen cycle in a river basin regardless of political borders.

Acknowledgements - Marcos D.B Watanabe thanks FAPESP (Foundation for Research Support of the State of São Paulo) for the PhD grant, organising support from INPE and data from Embrapa Informática Agropecuária (CNPTIA). 


\section{References}

Agência Nacional de Águas - ANA, 2001. Bacias brasileiras do rio da Prata: Avaliações e propostas. Available from: <http:// www.iph.ufrgs.br/corpodocente/tucci/publicacoes/relprata.PDF>. Access in: jan. 2011.

ASSAD, ED., PINTO, HS., ZULLO JUNIOR, J., MARIN, FR., PELLEGRINO, GQ., EVANGELISTA, SR. and OTAVIAN, AF., 2008. Aquecimento Global e a Nova Geografia da produção Agrícola no Brasil. Brasília: Embaixada Britânica. vol. 1, 82 p.

Associação Brasileira da Indústria Produtora e Exportadora de Carne Suína - ABIPECS, 2002. Relatório Anual 2002: O Agronegócio Brasileiro de Exportação. Available from: <http:// www.abipecs.org.br/uploads/relatorios/relatorios-associados/ ABIPECS_relatorio_2002_pt.pdf>. Access in: jna. 2011.

Associação Brasileira dos Produtores e Exportadores de Frangos - ABEF, 2002. Relatório Anual 2002. Available from: <http:// www.abef.com.br/portal/_clientes/abef/cat/ABEFportugues_9218. pdf>. Access in: jan. 2011.

ATTARD, E., 2010. Soil environmental conditions rather than denitrifier abundance and diversity drive potential denitrification after changes in land uses. Global Change Biology, vol. 17, no. 5, p. 1975-1989. http://dx.doi.org/10.1111/j.1365-2486.2010.02340.x

BALDANI, JI., OLIVEIRA, ALM., GUIMARÃES, SL., BALDANI, VLD., REIS, F.B., SILVA, LG., REIS, VM., TEIXEIRA, KRS. and DÖBEREINER, J., 2002. Biological nitrogen fixation (BNF) in non-leguminous plants: the role of endophytic diazotrophs. In PEDROSA, FO., HUNGRIA, M., YATES, G., NEWTON, W.E. Nitrogen Fixation: From Molecules to Crop Productivity. Current Plant Science and Biotech. in Agriculture. vol. 38, section 8, p. 397-400.

BARBOSA FILHO, MP., FAGERIA, NK. and DA SILVA, OS., 2005. Fontes, doses e parcelamento da adubação nitrogenada em cobertura para feijoeiro comum irrigado. Ciência $e$ Agrotecnologia, vol. 29, p. 69-76. http://dx.doi.org/10.1590/ S1413-70542005000100008

BONETTO, C., ZALOCAR, Y., PLANAS, D. and PEDROZO, F., 1991. Responses of phytoplankton to experimental nutrient enrichment in the Paraguay, Bermejo and upper Parana rivers. Tropical Ecology, vol. 32, no. 1, p. 47-64.

BRAGA, B., ROCHA, O. and TUNDISI, J., 1998. Dams, and the environment: the brazilian experience. Water Resources Development, vol. 14, p.126-139. http://dx.doi.org/10.1080/07900629849358

CANADELL, JG., PATAKI, DE., GIFFORD, R., HOUGHTON, RA., LUO, Y., RAUPACH, MR., SMITH, P. and STEFFEN, W., 2007. Saturation of the terrestrial carbon sink. In CANADELL, JG., PATAKI DE. and PITELKA, LF. Terrestrial Ecosystems in a changing World. Berlin: IGBP Ser., Springer, p. 59-78.

Comissão Administradora do Rio Uruguai - CARU, 1993. Informe de avance programa de calidad de las aguas y control de la contaminacion del rio uruguay- etapa 1, 1987-1990. Publicaciones de la Comision Administradora del Rio Uruguay, Serie tecnico-cientifica, no. 2(1). Available from: <http://www.idrc. ca/en/ev-58878-201-1-DO_TOPIC.html>. Access in: jan. 2011.

Companhia Nacional de Abastecimento - CONAB, 2011. Evolução das culturas. Available from: <http://www.conab.gov.br/conteudos. php? $\mathrm{a}=1099 \& \mathrm{t}=2>$. Access in: 5 jan. 2011.

COSTA, FMP., 2006. Crescimento e desenvolvimento do cafeeiro sob efeito da adubação nitrogenada. Piracicaba: Escola Superior de Agricultura Luiz de Queiroz, Universidade de Sãqo Paulo. 80p. Tese de Doutorado em Agronomia.

CRUSCIOL, CAC., 2003. Absorção, exportação e eficiência de utilização de nutrientes pela cultura do arroz de terras altas em função de lâminas de água aplicadas por aspersão. Acta Scientiarum: Agronomy, vol. 25, p. 97-102.

Environmental Protection Agency - EPA, 2011. Basic Information about Regulated Drinking Water Contaminants: Basic Information about Nitrite (Measured as Nitrogen) in Drinking Water. Available from: <http://water.epa.gov/drink/contaminants/basicinformation/ nitrite.cfm>. Access in: mar. 2011.

Embrapa. Embrapa Informática Agropecuária - CNPTIA, 2010a. Mapa de uso do solo na Bacia do Prata Brasileira em 2002. Embrapa.

Embrapa. Embrapa Informática Agropecuária - CNPTIA, 2010b. CT-Hidro Project. Available from: <www.agritempo.gov.br/ cthidro>. Access in: fev. 2010.

FAGERIA, NK., SANTOS, AB. and STONE, LF., 2003. Manejo de Nitrogênio em Arroz Irrigado. Santo Antônio de Goiás: EMBRAPA-CNPAF. 4 p. Circular Técnica, no. 58.

FILOSO, S., MARTINELLI, LA., WILLIANS, MR., LARA, LB., KRUSCHE, A., BALLESTER, MV., VICTORIA, R. and DE CAMARGO, P.B., 2003. Land use and nitrogen export in the Piracicaba River basin, Southeast Brazil. Biogeochemistry, vol. 65 , p. 275-294.

FILOSO, S., MARTINELLI, LA., HOWARTH, RW. and BOYER, EW., 2006. Human activities changing the nitrogen cycle in Brazil. Biogeochemistry, vol. 79, p. 61-89.

Instituto FNP - FNP, 2006. Agrianual: Anuário da Agricultura Brasileira. São Paulo: Brasilform. 504 p.

GALLOWAY, JN., DENTENER, FJ., CAPONE, DG., BOYER, EW., HOWARTH, RW., SEITZINGER,SP., ASNER GP., CLEVELAND, CC., GREEN, PA., HOLLAND, EA., KARL, DA., MICHAELS, AF., PORTER, JH., TOWNSEND, AR. and VÖRÖSMARTY, CJ., 2004. Nitrogen cycles: past, present, future. Biogeochemistry, vol. 70, p. 153-226.

GRUBER, N. and GALLOWAY, JN., 2008. An Earth-system perspective of the global nitrogen cycle. Nature, vol. 451, p. 293296. PMid:18202647. http://dx.doi.org/10.1038/nature06592

HERVÉ, T. and MELO, NA., 2008. Atlas do Brasil: disparidades e dinâmicas do território. 2nd ed. São Paulo: EdUSP. cap. 5, p. $115-143$.

HOEGH-GULDBERG O. and BRUNO JF., 2010. The Impact of Climate Change on the World's Marine Ecosystems. Science, vol. 328, p. 1523-1528. PMid:20558709. http://dx.doi.org/10.1126/ science. 1189930

HOEGH-GULDBERG, O., MUMBY, PJ., HOOTEN, AJ., STENECK, RS., GREENFIELD P., GOMEZ, E., HARVELL, CD., SALE, PF., EDWARDS, AJ., CALDEIRA, K., KNOWLTON, N., EAKIN, CM., IGLESIAS-PRIETO, R., MUTHIGA, N., BRADBURY, RH., DUBI, A. and HATZIOLOS, ME., 2007. Coral Reefs Under Rapid Climate Change and Ocean Acidification. Science, vol. 318, p. 1737-1742.

HOWARTH, RW., BILLEN, G., SWANEY, D., TOWNSEND, A., JAWORSKY, N., LAJTHA, K., DOWNING, JA., ELMGERN, R., CARACO, N., JORDAN, T., BERENDSE, F., FRENEY, J., KUDEYAROV, V., MURDOCH, P. and ZHAO-LIANG, Z., 1996. Regional nitrogen budgets and riverine $\mathrm{N}$ and $\mathrm{P}$ fluxes 
for the drainages to the North Atlantic Ocean: natural and human influences. Biogeochemistry, vol. 35, p. 75-139. http://dx.doi. org/10.1007/BF02179825

HURET, M., DADOU, I., DUMAS, F., LAZURE, P. and GARÇON, V., 2005. Coupling physical and biogeochemical processes in the Rio de la Plata plume. Continental Shelf Research, vol. 25, p. 629-653. http://dx.doi.org/10.1016/j.csr.2004.10.003

IGREJA, ACM., BLISKA, FMM., FILGUEIRAS, GC., MARTINS, SS. and TIRADO, G., 2006. Fator locacional na produção brasileira de carne bovina: uma análise comparada utilizando estatísticas de produção inspecionada versus produção total. Instituto de Economia Agrícola. Available from: <http://www. iea.sp.gov.br/download/1083-martins.pdf>. Access in: jan. 2011.

Instituto Brasileiro de Geografia e Estatística - IBGE, 2006. Censo Agropecuário 2006 e Produção da pecuária municipal. Available from: <ttp://www.cetesb.sp.gov.br/tecnologia-ambiental/cas-ematividade/48-camara-ambiental-do-setor-de-abate--frigorifico-egraxaria>. Access in: jan. 2011.

Intergovernmental Panel on Climate Change - IPCC, 2000. IPCC Special Report: Emission Scenarios. Available from: <http://www. ipcc.ch/pdf/special-reports/spm/sres-en.pdf>. Access in: fev. 2011.

JACKSON, LE., BURGER, M. and CAVAGNARO, TR., 2008. Roots, Nitrogen Transformations and Ecosystem Services. Annual Reviews of Plant Biology, vol. 59, p. 341-63. PMid:18444903. http://dx.doi.org/10.1146/annurev.arplant.59.032607.092932

LAZZAROTTO, P., CALANCA, P., SEMENOV, M. and FUHRER, J., 2010. Transient responses to increasing $\mathrm{CO}_{2}$ and climate change in an unfertilized grass-clover sward. Climate Research, vol. 41, p. 221-232. http://dx.doi.org/10.3354/cr00847

LEWIS, WM., MELACK, JM., McDOWELL, WH., McCLAIN, M. and RICHEY, JE., 1999. Nitrogen yields from undisturbed watersheds in the Americas. Biogeochemistry, vol. 46, p. 149-162. http://dx.doi.org/10.1007/BF01007577

LIU, J., YOU, L., AMINI, M., OBERSTEINER, M., HERRERO, M., ZEHNDER, AJB. and YANG, H., 2010. A high-resolution assessment on global nitrogen flows in cropland. PNAS early edition, p. 1-6. Available from: http://www.pnas.org/content/ early/2010/03/31/0913658107>. Access in: jan 2011

MACKENZIE, FT., VER, LM. and LERMAN, A., 2002. Centuryscale nitrogen and phosphorus controls of the carbon cycle. Chemical Geology, vol. 190, p. 13-32. http://dx.doi.org/10.1016/ S0009-2541(02)00108-0

MARENGO, JA., LIEBMAN, B., GIMM, AM., MISRA, V., SILVA DIAS, PL., CAVALCANTI, IFA., CARVALHO, LMV., BERBERY, EH., AMBRIZZI, T., VERA, CS., SAULO, AC., NOGUES-PAEGLE, J., ZIPSE, E., SETH, A. and ALVES, LM. 2012. Review: Recent developments on the South American Monsoon system. International Journal of Climatology,vol. 32, p. 1-21. http://dx.doi.org/10.1002/joc.2254

MARTINELLI, LA., PICCOLO, MC., TOWNSEND, AR., VITOUSEK, PM., CUEVAS, E., McDowell, W., ROBERTSO, GP., SANTOS, OC. and TRESEDER, K., 1999. Nitrogen stable isotopic composition of leaves and soil: tropical versus temperate forests. Biogeochemistry, vol. 46, p. 45-65.

MATSON, PA., McDOWELL, WH., TOWNSEND AR. and VITOUSEK, PM, 1999. The globalization of $\mathrm{N}$ deposition: ecosystem consequences in tropical environments. Biogeochemistry, vol. 46, p. 67-83.
Millennium Ecosystem Assessment - MEA, 2005. Ecosystems and human well-being: Synthesis. Washington: Island Press. 138 p.

NAGY, GJ., GÓMEZ-ERACHE, M., LÓPEZ, CH. and PERDOMO, AC., 2002. Distribution patterns of nutrients and symptoms of eutrophication in the Rio de la Plata River estuary system. Hydrobiologia, vol. 475-476, p. 125-139. http://dx.doi. org/10.1023/A:1020300906000

NOBRE, CA., ASSAD, ED. and OYAMA, MD., 2005. O impacto do aquecimento global nos ecossitemas brasileiros e na agricultura. Scientific American Brasil, vol. 12, p. 70-75. Edição Especial.

PRETTY, JN., BRETT, C., GEE, D., HINE, RE., MASON, CF., MORISON, JIL., RAVEN, H., RAYMENT, MD. and VAN DER BIJL, G., 2000. An assessment of the total external costs of UK agriculture. Agricultural Systems, vol. 65, p. 13-136

ROCKSTRÖM, J., STEFFEN, W., NOONE, K., PERSSON, A., CHAPIN, FS., LAMBIN, E., LENTON, TM., SCHEFFER, M., FOLKE, C., SCHELLNHUBER, H., NYKVIST, B., DE WIT, CA., HUGHES, T., VAN DER LEEUW, S., RODHE, H., SÖRLIN, S.,SNYDER, PK., COSTANZA, R., SVEDIN, U., FALKENMARK, M., KARLBERG, L., CORELL, R.W., FABRY, VJ., HANSEN, J., WALKER, B., LIVERMAN, D., RICHARDSON, K., CRUTZEN, P. and FOLEY, J., 2009. Planetary Boundaries: Exploring the safe operating space of humanity. Ecology and Society, vol. 14, p. 1-32.

SETH, A., ROJAS, M. and RAUSCHER, SA., 2010. CMIP3 projected changes in the annual cycle of the South American Monsoon. Climatic Change, vol. 98, p. 331-357. http://dx.doi. org/10.1007/s10584-009-9736-6

SMIL, V., 1998. Nitrogen in crop production: an account of global flows. Global Biogeochemical Cycles, vol. 13, p. 647-662. http:// dx.doi.org/10.1029/1999GB900015

SOARES, W. and MARENGO, JA., 2008. Assessments of moisture fluxes east of the Andes in South America in a global warming scenario. International Journal of Climatology, vol. 29, no. 10, p. 1395-1414. http://dx.doi.org/10.1002/joc. 180

SOUZA, EFC., 2010. Adubação nitrogenada e inoculação com rizóbio no feijoeiro em sucessão ao milho consorciado com braquiárias no sistema de platio direto. Botucatu: Faculdade de Ciências Agronômicas, Universidade Estadual Paulista. 50 p. Dissertação de Mestrado em Agronomia.

Universidade de Campinas - UNICAMP, 2006. Tabela brasileira de composição de alimentos - TACO. Versão 2. 2nd ed. Campinas: UNICAMP/NEPA. Available from: <http://www.unicamp.br/nepa/ taco/contar/taco_versao2.pdf>. Access in: dez. 2010.

Variability of American Monsoon Systems - VAMOS, 2001. Climatology and Hydrology of the Plata Basin: Cuenca del Plata. World Climate Research Programme - WCRP. Available from: $<$ http://www.atmos.umd.edu/ berbery/lpb/science_plan.html $>$. Access in: dez. 2010.

WENDLING, A., ELTZ, FLL., CUBILLA, MM., AMADO, TJC., MIELNICZUK, J. and LOVATO, T., 2007. Trigo em sucessão ao milho e soja sob sistema plantio direto no Paraguai. Revista Brasileira de Ciência do Solo, vol. 31, p. 985-994. http://dx.doi. org/10.1590/S0100-06832007000500015

ZULLO JUNIOR, J., PINTO, HS., ASSAD, ED. and EVANGELISTA, SR., 2008. Potential Economic Impacts of Global Warming on Two Brazilian Commodities, according to IPCC Prognostics. Terrae, vol. 3, p. 1-28. 